\begin{tabular}{|c|l|}
\hline Title & $\begin{array}{l}\text { Structural determination of vanillin, isovanillin and ethylvanillin by means of gas electron diffraction and theoretical } \\
\text { calculations }\end{array}$ \\
\hline Author(s) & Egawa, Toru; Kameyama, A kiyo; Takeuchi, Hiroshi \\
\hline Citation & $\begin{array}{l}\text { Journal of Molecular Structure, 794(1-3), 92-102 } \\
\text { https://doi.org/10.1016/.mol struc.2006.01.042 }\end{array}$ \\
\hline Issue Date & 2006-08-07 \\
\hline Doc URL & http://hdl.handle.net/2115/14773 \\
\hline Type & article (author version) \\
\hline Additional Information & There are other files related to this item in HUSCAP. Check the above URL. \\
\hline File Information & JMS794 1-3.pdf ( 本文) \\
\hline
\end{tabular}

Instructions for use 


\title{
Structural determination of vanillin, isovanillin and ethylvanillin by means of gas electron diffraction and theoretical calculations
}

\author{
Toru Egawa ${ }^{*}$, Akiyo Kameyama, Hiroshi Takeuchi \\ Division of Chemistry, Graduate School of Science, Hokkaido University, \\ Sapporo 060-0810, Japan
}

(Received

)

\begin{abstract}
The molecular structures of vanillin (4-hydroxy-3-methoxybenzaldehyde), isovanillin (3-hydroxy-4-methoxybenzaldehyde) and ethylvanillin (3-ethoxy-4-hydroxybenzaldehyde) were determined by means of gas electron diffraction. Among them, vanillin and ethylvanillin have a vanilla odor but isovanillin smells differently. The nozzle temperatures were $125^{\circ} \mathrm{C}, 173{ }^{\circ} \mathrm{C}$ and $146^{\circ} \mathrm{C}$, for vanillin, isovanillin and ethylvanillin, respectively. The results of MP2 and B3LYP calculations with the $6-31 \mathrm{G}^{* *}$ basis set were used as supporting information. The MP2 calculations predicted that vanillin and isovanillin have two stable conformers and ethylvanillin has four stable conformers. The electron diffraction data were found to be consistent with these conformational compositions. The determined structural parameters $\left(r_{\mathrm{g}}\right.$ and $\left.\angle_{\alpha}\right)$ of vanillin are as follows: $\quad<r(\mathrm{C}-\mathrm{C}))_{\text {ring }}>=1.397(4) \AA ; r\left(\mathrm{C}_{1}-\mathrm{C}_{\text {aldehyde }}\right)=1.471(\leftarrow) \AA$; $r\left(\mathrm{C}_{3}-\mathrm{O}_{\mathrm{Me}}\right)=1.374(9) \AA ; r\left(\mathrm{C}_{4}-\mathrm{O}_{\mathrm{H}}\right)=1.361(\leftarrow) \AA ; r\left(\mathrm{O}-\mathrm{C}_{\mathrm{Me}}\right)=1.428(\leftarrow) \AA ; r(\mathrm{C}=\mathrm{O})=$ 1.214(8) $\AA ;<r(\mathrm{C}-\mathrm{H})>=1.110(11) \AA ; r(\mathrm{O}-\mathrm{H})=0.991(\leftarrow) \AA ; \angle \mathrm{C}_{6}-\mathrm{C}_{1}-\mathrm{C}_{2}=120.6(2)^{\circ}$; $\angle \mathrm{C}_{1}-\mathrm{C}_{2}-\mathrm{C}_{3}=118.8(\leftarrow)^{\circ} ; \angle \mathrm{C}_{1}-\mathrm{C}_{6}-\mathrm{C}_{5}=120.1(\leftarrow)^{\circ} ; \angle \mathrm{C}_{2}-\mathrm{C}_{1}-\mathrm{C}_{\text {aldehyde }}=122.7(18)^{\circ}$; $\angle \mathrm{C}_{1}-\mathrm{C}=\mathrm{O}=119.4(16)^{\circ} ; \angle \mathrm{C}_{4}-\mathrm{C}_{3}-\mathrm{O}_{\mathrm{Me}}=112.2(12)^{\circ} ; \angle \mathrm{C}_{3}-\mathrm{C}_{4}-\mathrm{O}_{\mathrm{H}}=119.1(\leftarrow)^{\circ}$; $\angle \mathrm{C}_{3}-\mathrm{O}-\mathrm{C}=121.7(29)^{\circ} . \quad$ Those of isovanillin are as follows: $\quad\left\langle r(\mathrm{C}-\mathrm{C})_{\text {ring }}>=1.402(4)\right.$
\end{abstract}

\footnotetext{
* Corresponding author. Phone: +81-11-706-3506; Fax: +81-11-706-4924. E-mail address: egawa@sci.hokudai.ac.jp
} 
$\AA ; r\left(\mathrm{C}_{1}-\mathrm{C}_{\text {aldehyde }}\right)=1.479(\leftarrow) \AA ; r\left(\mathrm{C}_{4}-\mathrm{O}_{\mathrm{Me}}\right)=1.369(9) \AA ; r\left(\mathrm{C}_{3}-\mathrm{O}_{\mathrm{H}}\right)=1.357(\leftarrow) \AA ;$ $r\left(\mathrm{O}-\mathrm{C}_{\mathrm{Me}}\right)=1.422(\leftarrow) \AA ; r(\mathrm{C}=\mathrm{O})=1.221(9) \AA ;<r(\mathrm{C}-\mathrm{H})>=1.114(14) \AA ; r(\mathrm{O}-\mathrm{H})=$ $0.995(\leftarrow) \AA ; \angle \mathrm{C}_{6}-\mathrm{C}_{1}-\mathrm{C}_{2}=120.2(3)^{\circ} ; \angle \mathrm{C}_{1}-\mathrm{C}_{2}-\mathrm{C}_{3}=119.0(\leftarrow)^{\circ} ; \angle \mathrm{C}_{1}-\mathrm{C}_{6}-\mathrm{C}_{5}=$ $119.9(\leftarrow)^{\circ} ; \angle \mathrm{C}_{2}-\mathrm{C}_{1}-\mathrm{C}_{\text {aldehyde }}=124.6(25)^{\circ} ; \angle \mathrm{C}_{1}-\mathrm{C}=\mathrm{O}=121.3(24)^{\circ} ; \angle \mathrm{C}_{3}-\mathrm{C}_{4}-\mathrm{O}_{\mathrm{Me}}=$ 114.4(12) ${ }^{\circ} ; \angle \mathrm{C}_{4}-\mathrm{C}_{3}-\mathrm{O}_{\mathrm{H}}=121.2(\leftarrow)^{\circ} ; \angle \mathrm{C}_{4}-\mathrm{O}-\mathrm{C}=123.8(26)^{\circ}$. Those of ethylvanillin are as follows: $\quad<r(\mathrm{C}-\mathrm{C})_{\text {ring }}>=1.397(6) \AA ; r\left(\mathrm{C}_{1}-\mathrm{C}_{\text {aldehyde }}\right)=1.471(\leftarrow) \AA ; r\left(\mathrm{C}_{3}-\mathrm{O}_{\mathrm{Et}}\right)=$ 1.365(13) $\AA ; r\left(\mathrm{C}_{4}-\mathrm{O}_{\mathrm{H}}\right)=1.352(\leftarrow) \AA ; r\left(\mathrm{O}-\mathrm{C}_{\mathrm{Et}}\right)=1.427(\leftarrow) \AA ; r(\mathrm{C}-\mathrm{C})_{\mathrm{Et}}=1.494(21) \AA ;$ $r(\mathrm{C}=\mathrm{O})=1.206(9) \AA ;<r(\mathrm{C}-\mathrm{H})>=1.109(10) \AA ; r(\mathrm{O}-\mathrm{H})=0.990(\leftarrow) \AA ; \angle \mathrm{C}_{6}-\mathrm{C}_{1}-\mathrm{C}_{2}=$ $120.2(3)^{\circ} ; \angle \mathrm{C}_{1}-\mathrm{C}_{2}-\mathrm{C}_{3}=118.4(\leftarrow)^{\circ} ; \angle \mathrm{C}_{1}-\mathrm{C}_{6}-\mathrm{C}_{5}=119.7(\leftarrow)^{\circ} ; \angle \mathrm{C}_{2}-\mathrm{C}_{1}-\mathrm{C}_{\text {aldehyde }}=$ $121.7(21)^{\circ} ; \angle \mathrm{C}_{1}-\mathrm{C}=\mathrm{O}=128.8(22)^{\circ} ; \angle \mathrm{C}_{4}-\mathrm{C}_{3}-\mathrm{O}_{\mathrm{Et}}=112.8(14)^{\circ} ; \angle \mathrm{C}_{3}-\mathrm{C}_{4}-\mathrm{O}_{\mathrm{H}}=$ $119.6(\leftarrow)^{\circ} ; \angle \mathrm{C}_{3}-\mathrm{O}-\mathrm{C}=115.1(27)^{\circ} ; \angle \mathrm{O}-\mathrm{C}-\mathrm{C}_{\mathrm{Et}}=102.7(28)^{\circ}$. Angle brackets denote average values; parenthesized values are the estimated limits of error $(3 \sigma)$ referring to the last significant digit; left arrows in the parentheses mean that these parameters are bound to the preceding one.

: Vanillin; Isovanillin; Ethylvanillin; Molecular structure; Gas electron diffraction; MP2 calculations; DFT calculations

\section{Introduction}

Recently, we have been focusing on the structure determination of some bioactive compounds including odorant molecules and have investigated the geometrical structures and conformational properties of minty compounds, menthol and carvone, as well as isomenthol, that is the non-minty isomer of menthol, by means of gas electron diffraction $[1,2]$. The conformation of carvone has been further studied by laser-jet spectroscopy [3]. Vanillin (4-hydroxy-3-methoxybenzaldehyde) and related molecules, isovanillin (3-hydroxy-4-methoxybenzaldehyde) and ethylvanillin (3-ethoxy-4-hydroxybenzaldehyde), have been chosen as the second group of targets of 
this project in the present study (see Fig. 1). Vanillin is included in the vanilla bean extract and has a characteristic vanilla odor and ethylvanillin has a stronger vanilla odor than vanillin. On the other hand, isovanillin has almost no, if any, odor of vanilla.

The recognition of vanillin and ethylvanillin by their olfactory receptors has been investigated by Touhara and co-workers recently [4]. They identified the receptor of eugenol (a compound with a odor of clove), mOR-EG, and that of ethylvanillin, mOR-EV, and measured the sensitivity of various odorant molecules that have the structural resemblance to ethylvanillin and eugenol, to these receptors . Their results showed that vanillin and isovanillin are recognized by mOR-EG and mOR-EV differently. Vanillin is more sensitive than ethylvanillin to mOR-EG, but the order is reversed for their sensitivity with mOR-EV. No other compound than vanillin and ethylvanillin was recognized by the ethylvanillin receptor, mOR-EV [4].

Although it has been pointed out that the stereochemical structure of odorant molecule is the essential factor in the molecular recognition by olfactory receptors, most of the discussions are not based on the experimentally determined geometrical structures of the odorant molecules, and it is expected that the reliable molecular structures of them will contribute to the investigation of the molecular recognition by the receptors.

As for vanillin and isovanillin, X-ray diffraction studies of crystal have been reported $[5,6]$. However, the solid-phase structures are not suitable for the study of the structure-function relationship of bioactive molecules, because they are subject to the distortion caused by the packing effect. In the present study, the molecular structures and conformation of the title compounds have been investigated by means of gas electron diffraction and theoretical calculations in order to provide the "distortion-free" structural parameters.

\section{Experimental}

The samples of vanillin, isovanillin and ethylvanillin with purity of $99 \%$ were 
purchased from Aldrich Chemical Co. and were used without further purification. Electron diffraction patterns were recorded on 8 in. $\times 8$ in. Kodak projector slide plates with an apparatus equipped with an $r^{3}$-sector [7]. The camera distance was about 244 $\mathrm{mm}$ to cover the s-range sufficient for the molecules of this size. These samples have insufficient vapor pressure for the electron diffraction experiment at room temperature, in spite of their distinct smells. Therefore, the samples were heated by using the nozzle reported in Ref. [8]. The acceleration voltage of incident electrons was about $37 \mathrm{kV}$ and the electron wavelength was calibrated to the $r_{\mathrm{a}}(\mathrm{C}=\mathrm{S})$ distance of $\mathrm{CS}_{2}(1.5570 \AA)$ [9]. Other experimental conditions are summarized in Table 1. The photographic plates were developed for $4.5 \mathrm{~min}$. in a Dektol developer diluted 1:1. The photometry process was described in detail elsewhere [10]. The experimental intensities and backgrounds are available as Supplementary Information (Table S1).

Elastic atomic scattering factors were calculated as described in Ref. [11], and inelastic ones were taken from Ref. [12]. The experimental molecular scattering intensities are shown in Fig. 2 with the final calculated ones. A diagonal weight matrix was used in the least-squares analysis on the molecular scattering intensities.

\section{Theoretical calculations}

Possible conformers. The planar skeleton can be assumed for the case of vanillin and isovanillin, and hence, conformational variation is brought about by the combination of the internal rotation by $180^{\circ}$ of the three single bonds, $\mathrm{C}_{\text {ring }}-\mathrm{CHO}$, $\mathrm{C}_{\text {ring }}-\mathrm{OMe}$ and $\mathrm{C}_{\text {ring }}-\mathrm{OH}$. The geometrical optimizations of the various conformers of vanillin at the MP2(frozen core)/6-31G** level of theory revealed that the energies of the two conformers shown in Fig. 1 are lower than those of other conformers by more than $20 \mathrm{~kJ} / \mathrm{mol}$. This is fully consistent with the results of the calculations by using the MP2 and B3LYP methods with the similar basis set, 6-31G* reported by Velcheva and Stamboliyska recently [13]. These results seem reasonable because the methoxy and 
hydroxyl groups of these conformers are oriented so that an intramolecular hydrogen bond is formed between the hydroxyl $\mathrm{H}$ and the methoxy $\mathrm{O}$ atoms. Therefore the possibility of the other conformers was ruled out and only these conformers were considered in the following analysis. They are labeled s-cis and s-trans according to the orientation of the aldehyde group with respect to the methoxy group (see Fig. 1). The conformers of isovanillin have been labeled similarly. In the case of ethylvanillin, both of the s-cis and s-trans forms are further classified according to the orientation of the ethyl $\mathrm{C}-\mathrm{C}$ bond (trans and gauche) caused by the internal rotation of the ethyl group. Therefore, there can be four conformers in total and they are labeled s-cis-trans, s-trans-trans, s-cis-gauche and s-trans-gauche. All the possible conformers are shown in Fig. 1.

MP2 and B3LYP calculations. Geometry optimizations of the conformers shown in Fig. 1 were carried out at the MP2(frozen core)/6-31G** level of theory. Program GAUSSIAN 98 [14] was used. The obtained geometrical parameters and energies are listed in Tables 2 to 4 . The relative abundance of the conformers at the nozzle temperature for each molecule was estimated by using the obtained energies as listed in these Tables. It is worth noting that the energy difference between the s-trans and s-cis conformers of isovanillin $(0.08 \mathrm{~kJ} / \mathrm{mol})$ is significantly smaller than the corresponding values of vanillin and ethylvanillin $(4.73$ to $5.04 \mathrm{~kJ} / \mathrm{mol})$. This will be discussed later.

The vibrational calculations for all the possible conformers shown in Fig.1 were carried out with the B3LYP method and the 6-31G** basis set. The obtained Cartesian force constants were used for the following normal vibration analysis.

\section{Analyses}

Normal vibration analysis. The Cartesian force constants obtained by the B3LYP/6-31G** calculations were transformed into the force constants, $f_{i j}$, for the 
internal coordinates. The theoretical $f_{i j}$ 's of vanillin were modified by the scaling method so as to reproduce the experimental vibrational wavenumbers obtained from the IR spectrum measured in the $\mathrm{CCl}_{4}$ solution [15]. The linear scaling formula $f_{i j}$ (scaled) $=\left(c_{i} c_{j}\right)^{1 / 2} f_{i j}$ (unscaled) was used where $c_{i}$ is a scale factor [16]. The definitions of internal coordinates with the resultant scale factors are listed in Table S2 of Supplementary Information. The observed and calculated vibrational wavenumbers are listed in Table S3 of Supplementary Information. The obtained scale factors, $c_{i}$, of vanillin were used to calculate the force constants, $f_{i j}$, of isovanillin and ethylvanillin. The scale factor $c$ of 0.92 was assumed for the ethoxy group related internal coordinates of ethylvanillin, for which there is no corresponding value of vanillin.

Analysis of electron diffraction data. The following treatments were adopted on the results of the MP2/6-31G** geometry optimizations in order to reduce the number of adjustable parameters: (1) planar skeletons were assumed with the exception of the s-cis-gauche and s-trans-gauche conformers of ethylvanillin, for which the planarity was not assumed for the ethyl group; (2) the differences among the ring $\mathrm{C}-\mathrm{C}$ bonds and the $\mathrm{C}_{1}-\mathrm{C}_{7}$ single bonds were set equal to their theoretical values; (3) the differences among the three $\mathrm{C}-\mathrm{O}$ single bonds were set equal to their theoretical values; (4) the differences among all the $\mathrm{C}-\mathrm{H}$ and $\mathrm{O}-\mathrm{H}$ bonds were set equal to their theoretical values; (5) the difference between the $\mathrm{C}_{\text {ring }}-\mathrm{C}_{\text {ring }}-\mathrm{O}_{\text {methoxy/ethoxy }}$ and $\mathrm{C}_{\text {ring }}-\mathrm{C}_{\text {ring }}-\mathrm{O}_{\text {hydroxyl }}$ angles was set equal to their theoretical values; (6) the differences among the three angles in the ring, $\mathrm{C}_{2}-\mathrm{C}_{1}-\mathrm{C}_{6}, \mathrm{C}_{1}-\mathrm{C}_{2}-\mathrm{C}_{3}$ and $\mathrm{C}_{1}-\mathrm{C}_{6}-\mathrm{C}_{5}$, were set equal to their theoretical values; (7) the $\mathrm{C}-\mathrm{C}(=\mathrm{O})-\mathrm{H}$ angle in the aldehyde group was assumed to be equal to that of benzaldehyde, $115.1^{\circ}[17]$; (8) the $\mathrm{C}_{\text {ring }}-\mathrm{O}-\mathrm{H}$ angle was assumed to be equal to that of phenol, $106.4^{\circ}[18]$; (9) the $\mathrm{C}_{\text {ring }}-\mathrm{H}$ bonds were assumed to bisect the $\mathrm{C}-\mathrm{C}-\mathrm{C}$ angle; (10) the angles in the methyl or ethyl group containing the $\mathrm{C}-\mathrm{H}$ bond were set equal to their theoretical values. For the s-cis-gauche and s-trans-gauche conformers of ethylvanillin, the additional treatments were adopted as follows: (11) the ethyl torsional angle, 
$\mathrm{C}_{3}-\mathrm{O}_{9}-\mathrm{C}_{10}-\mathrm{C}_{11}$, was set equal to their theoretical values; (12) the torsional angle, $\mathrm{C}_{2}-$ $\mathrm{C}_{3}-\mathrm{O}_{9}-\mathrm{C}_{10}$, was set equal to their theoretical values. The assumption (11) had to be adopted because a reasonable convergence of the least-squares fitting could not be obtained when this dihedral angle was varied, contrary to our initial expectation to determine it. The independent parameters and the constraints are summarized in Tables 5 to 7.

Mean amplitudes, $l$, and shrinkage corrections, $r_{\mathrm{a}}-r_{\alpha}$ [19], were calculated from the above-mentioned scaled force constants. The model of small-amplitude vibrations was adopted. The mean amplitudes were adjusted in groups. The groups were separated according to the $r_{\mathrm{a}}$ distances of the atomic pairs. The differences among the mean amplitudes in each group were fixed at the calculated values. Table S4 of Supplementary Information list the mean amplitudes with the corresponding $r_{\mathrm{a}}$ distances. The anharmonicity parameters, $\kappa[20]$, for bonded atom pairs were estimated in a diatomic approximation, $\kappa=(a / 6) l^{4}[21]$, where the Morse parameter, $a$, was assumed to be $2.0 \AA^{-1}$. Those for nonbonded atom pairs were assumed to be zero.

\section{Results and discussions}

All the effort to determine the s-cis over s-trans abundance ratio of vanillin (trying various set of constraints, for example) were in vain: the uncertainty of the abundance $(3 \sigma)$ exceeded the absolute value of the abundance of the s-trans, or the abundance of the s-trans resulted in a negative value. So, it was decided to fix the s-cis over s-trans ratio of vanillin as well as isovanillin at the theoretical value obtained from the MP2/6-31G** calculations (81/19 for vanillin and 51/49 for isovanillin, see Tables 2 and 3). On the other hand, a significant result was obtained in determining the trans vs. gauche abundance ratio of ethylvanillin when the ratios, s-cis-trans over s-trans-trans and s-cis-gauche over s-trans-gauche, were fixed to the theoretical values listed in Table $4(45 / 12$ and 35/8, respectively) and then the ratio (s-cis-trans + s-trans-trans) over 
(s-cis-gauche + s-trans-gauche) was varied. This treatment is equivalence of assuming the energy differences caused by the positional change of the aldehyde group of ethylvanillin from the s-cis to s-trans to be equal to the MP2 values, as in the case of vanillin and isovanillin. The obtained abundances of the s-cis-trans, s-trans-trans, s-cis-gauche and s-trans-gauche conformers of ethylvanillin are $35 \%, 9 \%, 45 \%$ and $11 \%$, respectively. The uncertainty for the abundance of s-cis-trans + s-trans-trans $(44 \%$ in total) is $\pm 27 \%$.

The MP2/6-31G** calculations predicted the relative stability for the two conformers of isovanillin quite differently from that of vanillin. The calculated energy difference between the s-trans and s-cis conformers of vanillin is about $5 \mathrm{~kJ} / \mathrm{mol}$ and that of isovanillin is less than $0.1 \mathrm{~kJ} / \mathrm{mol}$ (see Tables 2 and 3) and consequently, the predicted abundance ratio of the conformers for the latter is about 1:1. Although these conformational properties are not supported experimentally but totally theoretical, it is worthwhile to try giving them a qualitative (and speculative) explanation by means of a quite simple model. According to the atomic charge distribution obtained from the natural population analysis [22], the electric dipole of the aldehyde group of vanillin and isovanillin lies commonly on the $\mathrm{C}_{7}=\mathrm{O}_{8}$ bond with the positive charge end at the position of the $\mathrm{C}_{7}$ atom. On the other hand, the electric dipole of the rest of the atoms in vanillin has a comparable magnitude and it lies approximately on the $\mathrm{C}_{3}-\mathrm{C}_{4}$ bond with the positive end at the position of the $\mathrm{C}_{3}$ atom independently of the conformation (s-cis and s-trans). Therefore, the two electric dipoles of the s-cis conformer are directed in a counter parallel manner so that this conformer is expected to have lower energy than the s-trans conformer, whose electric dipoles are directed perpendicularly. For isovanillin, however, the positive end of the electric dipole is at the position of the $\mathrm{C}_{4}$ atom and hence the relative relationship of the two dipoles of the s-cis conformer is parallel and that of the s-tans is perpendicular, anticipating the higher energy for the s-cis conformer than the s-trans. Of course, this explanation is too simplified, because this model predicts that 
the conformational stability of the s-cis and s-trans conformers of isovanillin is opposite to that of vanillin, whereas the actual calculated energy for the s-trans of isovanillin is still slightly higher than that of the s-cis. However, more sophisticated explanation is out of the scope of the present work, and above all, the conformational properties of these molecules should be further investigated with spectroscopic methods.

Table 8 lists the obtained structural parameters for the s-cis conformer of vanillin and isovanillin and those for the s-cis-trans conformer of ethylvanillin. Experimental radial distribution curves with residuals are shown in Fig. 3. The resultant $R$-factors ${ }^{1}$ were $0.044,0.054$ and 0.047 for vanillin, isovanillin and ethylvanillin, respectively. The indices of resolution, $k,{ }^{2}$ for them were $0.94 \pm 0.02,0.86 \pm 0.02$ and $0.88 \pm 0.02$, respectively. The correlation matrices are listed in Table S5 of Supplementary Information. It was common to all the three molecules that only one element of the correlation matrix, $r(\mathrm{C}-\mathrm{C})$ vs. $r(\mathrm{C}-\mathrm{O})$, had the absolute value larger than 0.9 .

The theoretical structural parameters obtained from the MP2/6-31G** and B3LYP/6-31G** calculations are compared with the experimental ones in Table 8. For the bond lengths, the $\mathrm{C}-\mathrm{O}$ and $\mathrm{C}-\mathrm{C}$ bonds showed satisfactory agreement between the experimental and theoretical values, but the calculations failed to reproduce the $\mathrm{C}-\mathrm{H} / \mathrm{O}-\mathrm{H}$ and $\mathrm{C}=\mathrm{O}$ bond lengths. As for the bond angles, disagreement was found for some bond angles such as $\angle \mathrm{C}-\mathrm{O}-\mathrm{C}, \angle \mathrm{C}_{2}-\mathrm{C}_{1}-\mathrm{C}_{7}$ and $\angle \mathrm{C}-\mathrm{C}=\mathrm{O}$. It should be also noted that there is no significant difference between the MP2 and DFT structural parameters in regard to the agreement with the experimental results.

For vanillin and isovanillin, the structural parameters obtained form the X-ray diffraction studies $[5,6]$ are compared in Table 9. There are some amounts of

${ }^{1} R$-factor is defined as $R=\left\{\sum_{i} W_{i}\left(\Delta s M(s)_{i}\right)^{2} / \sum_{i} W_{i}\left(s M(s)_{i}{ }^{\text {obs }}\right)^{2}\right\}^{1 / 2}$, where $\Delta s M(s)_{i}=s M(s)_{i}{ }^{\text {obs }}-s M(s)_{i}{ }^{\text {calc }}$ and $W_{i}$ is a diagonal element of the weight matrix.

${ }^{2} k$ is defined as $s M(s)^{\text {obs }}=k s M(s)^{\text {calc }}$. 
differences between the gas-phase and crystal values of many structural parameters. Among them, the most characteristic ones are found for the $\mathrm{C}-\mathrm{C}=\mathrm{O}$ and $\mathrm{C}-\mathrm{O}-\mathrm{C}$ angles. The values of the $\mathrm{C}-\mathrm{C}=\mathrm{O}$ angle for the crystal, $126.1 \pm 0.2^{\circ}$ and $125.3 \pm 0.5^{\circ}$ for vanillin and isovanillin, respectively, are significantly larger than the corresponding gas-phase values, $119.4 \pm 1.6^{\circ}$ and $121.1 \pm 2.4^{\circ}$. The large $\mathrm{C}-\mathrm{C}=\mathrm{O}$ angles in the crystal might be due to the intermolecular hydrogen bond between the $\mathrm{C}=\mathrm{O}$ and $\mathrm{O}-\mathrm{H}$ groups.

Finally, the structural parameters obtained in the present study are compared with those of the related molecules, benzaldehyde [17], anisole [23] and phenol [18], in Table 10. Most of the corresponding parameters are in moderate agreement with each other. Therefore it can be concluded that the mutual influence between the side chain groups, aldehyde, methoxy, hydroxyl and ethoxy, on the structural parameters is not very large.

\section{Supplementary information}

Tables of the leveled total intensities and the backgrounds, definitions of the internal coordinates with the scale factors, observed and calculated vibrational wavenumbers of vanillin, mean amplitudes, and the correlation matrices are deposited with B.L.L.D. as publication No. SUP .

\section{Acknowledgements}

The authors thank the Research Center for Computational Science, Okazaki Japan, for the use of the Fujitsu VPP5000 computer and the Library Program GAUSSIAN 98. T. E. thanks Shigehiro Konaka, Professor Emeritus of Hokkaido University, for his critical reading of the manuscript.

\section{References}

[1] T. Egawa, Y. Kachi, T. Takeshima, H. Takeuchi, S. Konaka, J. Mol. Struct., 658 
(2003) 241.

[2] T. Egawa, M. Sakamoto, H. Takeuchi, S. Konaka, J. Phys. Chem. A, 107 (2003) 2757.

[3] M. Mineyama, T. Egawa, J. Mol. Struct., 734 (2005) 61.

[4] K. Kajiya, K. Inaki, M. Tanaka, T. Haga, H. Kataoka, K. Touhara, J. Neurosci., 21 (2001) 6018 .

[5] R. Velavan, P. Sureshkumar, K. Sivakumar, S. Natarajan, Acta Cryst., C51 (1995) 1131.

[6] F. Iwasaki, Chem. Lett., (1973) 227.

[7] S. Konaka, M. Kimura, 13th Austin Symposium on Gas Phase Molecular Structure, 12-14 March, The University of Texas, Austin, TX, 1990, S21.

[8] N. Kuze, M. Ebizuka, H. Fujiwara, H. Takeuchi, T. Egawa, S. Konaka, G. Fogarasi, J. Phys. Chem. A, 102 (1998) 2080.

[9] A. Tsuboyama, A. Murayama, S. Konaka, M. Kimura, J. Mol. Struct., 118 (1984) 351.

[10] N. Kuze, H. Fujiwara, H. Takeuchi, T. Egawa, S. Konaka, G. Fogarasi, J. Phys. Chem. A, 103 (1999) 3054.

[11] M. Kimura, S. Konaka, M. Ogasawara, J. Chem. Phys., 46 (1967) 2599.

[12] C. Tavard, D. Nicolas, M. Rouault, J. Chim. Phys. Phys.-Chim. Biol., 64 (1967) 540.

[13] E. A. Velcheva, B. A. Stamboliyska, Spectrochim. Acta, A60 (2004) 2013.

[14] Gaussian 98, Revision A.9, M. J. Frisch, G. W. Trucks, H. B. Schlegel, G. E. Scuseria, M. A. Robb, J. R. Cheeseman, V. G. Zakrzewski, J. A. Montgomery Jr., R. E. Stratmann, J. C. Burant, S. Dapprich, J. M. Millam, A. D. Daniels, K. N. Kudin, M. C. Strain, O. Farkas, J. Tomasi, V. Barone, M. Cossi, R. Cammi, B. Mennucci, C. Pomelli, C. Adamo, S. Clifford, J. Ochterski, G. A. Petersson, P. Y. Ayala, Q. Cui, K. Morokuma, D. K. Malick, A. D. Rabuck, K. Raghavachari, J. B. Foresman, J. 
Cioslowski, J. V. Ortiz, A. G. Baboul, B. B. Stefanov, G. Liu, A. Liashenko, P. Piskorz, I. Komaromi, R. Gomperts, R. L. Martin, D. J. Fox, T. Keith, M. A. Al-Laham, C. Y. Peng, A. Nanayakkara, M. Challacombe, P. M. W. Gill, B. Johnson, W. Chen, M. W. Wong, J. L. Andres, C. Gonzalez, M. Head-Gordon, E. S. Replogle, J. A. Pople, Gaussian, Inc., Pittsburgh PA, 1998.

[15] SDBSWeb : http://www.aist.go.jp/RIODB/SDBS/(Oct., 2000).

[16] J. E. Boggs, in I. Hargittai and M. Hargittai (Ed.), Stereochemical Applications of Gas-phase Electron Diffraction, Part B, VCH, New York, 1988, Chapter 10.

[17] K. B. Borisenko, C. W. Bock, I. Hargittai, J. Phys. Chem., 100 (1996) 7426.

[18] G. Portalone, G. Shultz, A. Domenicano, I. Hargittai, Chem. Phys. Lett., 197 (1992) 482.

[19] K. Kuchitsu, S. J. Cyvin, in S. J. Cyvin (Ed.), Molecular Structures and Vibrations, Elsevier, Amsterdam, 1972, Chapter 12.

[20] K. Kuchitsu, Bull. Chem. Soc. Jpn., 40 (1967) 505.

[21] K. Kuchitsu, L. S. Bartell, J. Chem. Phys., 35 (1961) 1945.

[22] NBO, Version 3.1, E. D. Glendening, A. E. Reed, J. E. Carpenter, F. Weinhold,

[23] H. M. Seip, R. Seip, Acta Chem. Scand., 27 (1973) 4024. 
Table 1

Experimental conditions of gas electron diffraction experiments for vanillin, isovanillin and ethylvanillin

\begin{tabular}{llll}
\hline & Vanillin & Isovanillin & Ethylvanillin \\
\hline Camera distance / mm & 244.18 & 244.35 & 244.37 \\
Nozzle temperature / K & 398 & 446 & 419 \\
Electron wavelength / $\AA$ & 0.06334 & 0.06326 & 0.06326 \\
Uncertainty in the scale factor / \% & 0.05 & 0.04 & 0.10 \\
Background pressure during exposure / $10^{-6}$ Torr & $5.0-6.0$ & $4.1-4.8$ & $2.6-3.0$ \\
Beam current / $\mu \mathrm{A}$ & $1.24-1.27$ & $1.41-1.48$ & $1.38-1.39$ \\
Exposure time / s & $65-74$ & $68-96$ & $65-70$ \\
Number of plates used & 3 & 4 & 4 \\
Range of $s$ value / $\AA^{-1}$ & $4.7-33.8$ & $4.7-33.8$ & $4.5-33.5$ \\
\hline
\end{tabular}


Table 2

Geometrical parameters and relative energies of the s-cis and s-trans conformers of vanillin obtained from the MP2/6-31G** calculations

\begin{tabular}{|c|c|c|}
\hline Parameters ${ }^{a}$ & $\mathrm{~s}-c i s$ & s-trans \\
\hline \multicolumn{3}{|c|}{ Bond lengths / Å } \\
\hline $\mathrm{C}_{1}-\mathrm{C}_{2}$ & 1.406 & 1.405 \\
\hline $\mathrm{C}_{2}-\mathrm{C}_{3}$ & 1.386 & 1.390 \\
\hline $\mathrm{C}_{3}-\mathrm{C}_{4}$ & 1.414 & 1.410 \\
\hline $\mathrm{C}_{4}-\mathrm{C}_{5}$ & 1.391 & 1.394 \\
\hline $\mathrm{C}_{5}-\mathrm{C}_{6}$ & 1.395 & 1.392 \\
\hline $\mathrm{C}_{1}-\mathrm{C}_{6}$ & 1.397 & 1.399 \\
\hline $\mathrm{C}_{1}-\mathrm{C}_{7}$ & 1.472 & 1.474 \\
\hline $\mathrm{C}_{3}-\mathrm{O}_{9}$ & 1.373 & 1.375 \\
\hline $\mathrm{C}_{4}-\mathrm{O}_{11}$ & 1.361 & 1.361 \\
\hline $\mathrm{O}_{9}-\mathrm{C}_{10}$ & 1.428 & 1.426 \\
\hline $\mathrm{C}_{7}=\mathrm{O}_{8}$ & 1.229 & 1.228 \\
\hline $\mathrm{C}_{7}-\mathrm{H}_{12}$ & 1.106 & 1.107 \\
\hline $\mathrm{C}_{2}-\mathrm{H}_{13}$ & 1.081 & 1.082 \\
\hline $\mathrm{C}_{5}-\mathrm{H}_{18}$ & 1.082 & 1.082 \\
\hline $\mathrm{C}_{6}-\mathrm{H}_{19}$ & 1.084 & 1.082 \\
\hline $\mathrm{C}_{10}-\mathrm{H}_{14}$ & 1.085 & 1.085 \\
\hline $\mathrm{C}_{10}-\mathrm{H}_{15,16}$ & 1.090 & 1.091 \\
\hline $\mathrm{O}_{11}-\mathrm{H}_{17}$ & 0.970 & 0.970 \\
\hline
\end{tabular}

Bond angles $/^{\circ}$

$\mathrm{C}_{2}-\mathrm{C}_{1}-\mathrm{C}_{6}$

120.7

120.6 


\begin{tabular}{|c|c|c|}
\hline $\mathrm{C}_{1}-\mathrm{C}_{2}-\mathrm{C}_{3}$ & 118.9 & 119.2 \\
\hline $\mathrm{C}_{2}-\mathrm{C}_{3}-\mathrm{C}_{4}$ & 120.5 & 120.2 \\
\hline $\mathrm{C}_{3}-\mathrm{C}_{4}-\mathrm{C}_{5}$ & 120.2 & 120.1 \\
\hline $\mathrm{C}_{4}-\mathrm{C}_{5}-\mathrm{C}_{6}$ & 119.5 & 119.8 \\
\hline $\mathrm{C}_{1}-\mathrm{C}_{6}-\mathrm{C}_{5}$ & 120.2 & $120 .($ \\
\hline $\mathrm{C}_{2}-\mathrm{C}_{1}-\mathrm{C}_{7}$ & 119.2 & 119.1 \\
\hline $\mathrm{C}_{6}-\mathrm{C}_{1}-\mathrm{C}_{7}$ & 120.1 & 120.3 \\
\hline $\mathrm{C}_{1}-\mathrm{C}_{7}=\mathrm{O}_{8}$ & 124.4 & 124.6 \\
\hline $\mathrm{C}_{2}-\mathrm{C}_{3}-\mathrm{O}_{9}$ & 126.5 & 126.6 \\
\hline $\mathrm{C}_{4}-\mathrm{C}_{3}-\mathrm{O}_{9}$ & 113.0 & 113.2 \\
\hline $\mathrm{C}_{3}-\mathrm{C}_{4}-\mathrm{O}_{11}$ & 119.9 & 120.0 \\
\hline $\mathrm{C}_{5}-\mathrm{C}_{4}-\mathrm{O}_{11}$ & 120.0 & 119.9 \\
\hline $\mathrm{C}_{3}-\mathrm{O}_{9}-\mathrm{C}_{10}$ & 116.3 & 116.5 \\
\hline $\mathrm{C}_{1}-\mathrm{C}_{7}-\mathrm{H}_{12}$ & 114.9 & 114.8 \\
\hline $\mathrm{O}_{8}=\mathrm{C}_{7}-\mathrm{H}_{12}$ & 120.7 & 120.6 \\
\hline $\mathrm{C}_{1}-\mathrm{C}_{2}-\mathrm{H}_{13}$ & 118.3 & 119.5 \\
\hline $\mathrm{C}_{3}-\mathrm{C}_{2}-\mathrm{H}_{13}$ & 122.8 & 121.3 \\
\hline $\mathrm{C}_{4}-\mathrm{C}_{5}-\mathrm{H}_{18}$ & 118.5 & 118.3 \\
\hline $\mathrm{C}_{6}-\mathrm{C}_{5}-\mathrm{H}_{18}$ & 122.0 & 121.8 \\
\hline $\mathrm{C}_{5}-\mathrm{C}_{6}-\mathrm{H}_{19}$ & 120.0 & 121.3 \\
\hline $\mathrm{C}_{1}-\mathrm{C}_{6}-\mathrm{H}_{19}$ & 119.8 & 118.7 \\
\hline $\mathrm{C}_{4}-\mathrm{O}_{11}-\mathrm{H}_{17}$ & 106.5 & 106.6 \\
\hline $\mathrm{O}_{9}-\mathrm{C}_{10}-\mathrm{H}_{14}$ & 105.7 & 105.7 \\
\hline $\mathrm{O}_{9}-\mathrm{C}_{10}-\mathrm{H}_{15,16}$ & 110.8 & 110.9 \\
\hline $\mathrm{H}_{14}-\mathrm{C}_{10}-\mathrm{H}_{15,16}$ & 110.0 & 109.8 \\
\hline $\mathrm{H}_{15}-\mathrm{C}_{10}-\mathrm{H}_{16}$ & 109.6 & 109.6 \\
\hline
\end{tabular}


Dihedral angles ${ }^{\circ}$

$\begin{array}{lll}\mathrm{C}_{2}-\mathrm{C}_{1}-\mathrm{C}_{7}=\mathrm{O}_{8} & 0.0 & 180.0 \\ \mathrm{C}_{6}-\mathrm{C}_{1}-\mathrm{C}_{7}=\mathrm{O}_{8} & 180.0 & 0.0 \\ \mathrm{C}_{2}-\mathrm{C}_{1}-\mathrm{C}_{7}-\mathrm{H}_{12} & 180.0 & 0.0 \\ \mathrm{C}_{6}-\mathrm{C}_{1}-\mathrm{C}_{7}-\mathrm{H}_{12} & 0.0 & 180.0 \\ \mathrm{C}_{3}-\mathrm{O}_{9}-\mathrm{C}_{10}-\mathrm{H}_{14} & 180.0 & 180.0 \\ \mathrm{C}_{3}-\mathrm{O}_{9}-\mathrm{C}_{10}-\mathrm{H}_{15} & 60.9 & 61.0 \\ \mathrm{C}_{3}-\mathrm{O}_{9}-\mathrm{C}_{10}-\mathrm{H}_{16} & -60.9 & -61.0 \\ & & \\ \Delta E / \mathrm{kJ} \text { mol } & \\ \text { Abundance } / \% & & \\ \end{array}$

${ }^{a}$ See Fig. 1 for the atom numbering.

${ }^{\mathrm{b}}$ The absolute energy of the s-cis conformer is $-533.7807521 E_{\mathrm{h}}$.

${ }^{\mathrm{c}}$ Estimated from the energy difference, $\Delta E$, at $398 \mathrm{~K}$. 
Table 3

Geometrical parameters and relative energies of the s-cis and s-trans conformers of isovanillin obtained from the MP2/6-31G** calculations

\begin{tabular}{|c|c|c|}
\hline Parameters $^{\text {a }}$ & $\mathrm{s}-c i s$ & s-trans \\
\hline \multicolumn{3}{|c|}{ Bond lengths / $\AA$} \\
\hline $\mathrm{C}_{1}-\mathrm{C}_{2}$ & 1.403 & 1.402 \\
\hline $\mathrm{C}_{2}-\mathrm{C}_{3}$ & 1.385 & 1.388 \\
\hline $\mathrm{C}_{3}-\mathrm{C}_{4}$ & 1.414 & 1.410 \\
\hline $\mathrm{C}_{4}-\mathrm{C}_{5}$ & 1.394 & 1.396 \\
\hline $\mathrm{C}_{5}-\mathrm{C}_{6}$ & 1.398 & 1.395 \\
\hline $\mathrm{C}_{1}-\mathrm{C}_{6}$ & 1.397 & 1.398 \\
\hline $\mathrm{C}_{1}-\mathrm{C}_{7}$ & 1.475 & 1.476 \\
\hline $\mathrm{C}_{3}-\mathrm{O}_{9}$ & 1.362 & 1.363 \\
\hline $\mathrm{C}_{4}-\mathrm{O}_{10}$ & 1.373 & 1.374 \\
\hline $\mathrm{O}_{10}-\mathrm{C}_{11}$ & 1.427 & 1.427 \\
\hline $\mathrm{C}_{7}=\mathrm{O}_{8}$ & 1.228 & 1.228 \\
\hline $\mathrm{C}_{7}-\mathrm{H}_{12}$ & 1.107 & 1.106 \\
\hline $\mathrm{C}_{2}-\mathrm{H}_{13}$ & 1.082 & 1.084 \\
\hline $\mathrm{C}_{5}-\mathrm{H}_{18}$ & 1.080 & 1.081 \\
\hline $\mathrm{C}_{6}-\mathrm{H}_{19}$ & 1.084 & 1.082 \\
\hline $\mathrm{C}_{11}-\mathrm{H}_{15}$ & 1.085 & 1.085 \\
\hline $\mathrm{C}_{11}-\mathrm{H}_{16,17}$ & 1.090 & 1.090 \\
\hline $\mathrm{O}_{9}-\mathrm{H}_{14}$ & 0.969 & 0.969 \\
\hline
\end{tabular}

Bond angles $/^{\circ}$

$\mathrm{C}_{2}-\mathrm{C}_{1}-\mathrm{C}_{6}$

120.7

120.5 


\begin{tabular}{|c|c|c|}
\hline $\mathrm{C}_{1}-\mathrm{C}_{2}-\mathrm{C}_{3}$ & 119.4 & 119.7 \\
\hline $\mathrm{C}_{2}-\mathrm{C}_{3}-\mathrm{C}_{4}$ & 119.9 & 119.7 \\
\hline $\mathrm{C}_{3}-\mathrm{C}_{4}-\mathrm{C}_{5}$ & 120.8 & 120.7 \\
\hline $\mathrm{C}_{4}-\mathrm{C}_{5}-\mathrm{C}_{6}$ & 119.0 & 119.4 \\
\hline $\mathrm{C}_{1}-\mathrm{C}_{6}-\mathrm{C}_{5}$ & 120.3 & 120.1 \\
\hline $\mathrm{C}_{2}-\mathrm{C}_{1}-\mathrm{C}_{7}$ & 119.8 & 119.4 \\
\hline $\mathrm{C}_{6}-\mathrm{C}_{1}-\mathrm{C}_{7}$ & 119.6 & 120.0 \\
\hline $\mathrm{C}_{1}-\mathrm{C}_{7}=\mathrm{O}_{8}$ & 124.5 & 124.4 \\
\hline $\mathrm{C}_{2}-\mathrm{C}_{3}-\mathrm{O}_{9}$ & 120.3 & 120.2 \\
\hline $\mathrm{C}_{4}-\mathrm{C}_{3}-\mathrm{O}_{9}$ & 119.8 & 120.1 \\
\hline $\mathrm{C}_{3}-\mathrm{C}_{4}-\mathrm{O}_{10}$ & 113.0 & 113.1 \\
\hline $\mathrm{C}_{5}-\mathrm{C}_{4}-\mathrm{O}_{10}$ & 126.2 & 126.3 \\
\hline $\mathrm{C}_{4}-\mathrm{O}_{10}-\mathrm{C}_{11}$ & 116.8 & 116.8 \\
\hline $\mathrm{C}_{1}-\mathrm{C}_{7}-\mathrm{H}_{12}$ & 114.8 & 115.0 \\
\hline $\mathrm{O}_{8}=\mathrm{C}_{7}-\mathrm{H}_{12}$ & 120.7 & 120.7 \\
\hline $\mathrm{C}_{1}-\mathrm{C}_{2}-\mathrm{H}_{13}$ & 120.3 & 121.4 \\
\hline $\mathrm{C}_{3}-\mathrm{C}_{2}-\mathrm{H}_{13}$ & 120.3 & 118.9 \\
\hline $\mathrm{C}_{4}-\mathrm{C}_{5}-\mathrm{H}_{18}$ & 120.9 & 120.7 \\
\hline $\mathrm{C}_{6}-\mathrm{C}_{5}-\mathrm{H}_{18}$ & 120.1 & 119.9 \\
\hline $\mathrm{C}_{5}-\mathrm{C}_{6}-\mathrm{H}_{19}$ & 119.8 & 121.0 \\
\hline $\mathrm{C}_{1}-\mathrm{C}_{6}-\mathrm{H}_{19}$ & 119.9 & 118.9 \\
\hline $\mathrm{C}_{3}-\mathrm{O}_{9}-\mathrm{H}_{14}$ & 106.7 & 106.5 \\
\hline $\mathrm{O}_{10}-\mathrm{C}_{11}-\mathrm{H}_{15}$ & 105.7 & 105.6 \\
\hline $\mathrm{O}_{10}-\mathrm{C}_{11}-\mathrm{H}_{16,17}$ & 110.9 & 110.9 \\
\hline $\mathrm{H}_{15}-\mathrm{C}_{11}-\mathrm{H}_{16,17}$ & 109.8 & 109.8 \\
\hline $\mathrm{H}_{16}-\mathrm{C}_{11}-\mathrm{H}_{17}$ & 109.7 & 109.7 \\
\hline
\end{tabular}


Dihedral angles / ${ }^{\circ}$

$\begin{array}{lll}\mathrm{C}_{2}-\mathrm{C}_{1}-\mathrm{C}_{7}=\mathrm{O}_{8} & 0.0 & 180.0 \\ \mathrm{C}_{6}-\mathrm{C}_{1}-\mathrm{C}_{7}=\mathrm{O}_{8} & 180.0 & 0.0 \\ \mathrm{C}_{2}-\mathrm{C}_{1}-\mathrm{C}_{7}-\mathrm{H}_{12} & 180.0 & 0.0 \\ \mathrm{C}_{6}-\mathrm{C}_{1}-\mathrm{C}_{7}-\mathrm{H}_{12} & 0.0 & 180.0 \\ \mathrm{C}_{4}-\mathrm{O}_{10}-\mathrm{C}_{11}-\mathrm{H}_{15} & 180.0 & 180.0 \\ \mathrm{C}_{4}-\mathrm{O}_{10}-\mathrm{C}_{11}-\mathrm{H}_{16} & -61.0 & -61.1 \\ \mathrm{C}_{4}-\mathrm{O}_{10}-\mathrm{C}_{11}-\mathrm{H}_{17} & 61.0 & 61.1\end{array}$

$\begin{array}{lll}\Delta E / \mathrm{kJ} \mathrm{mol}^{-1 \mathrm{~b}} & 0.000 & 0.079\end{array}$

Abundance $/ \%^{\mathrm{c}} \quad 50.5 \quad 49.5$

${ }^{a}$ See Fig. 1 for the atom numbering.

${ }^{\mathrm{b}}$ The absolute energy of the s-cis conformer is $-533.7785465 E_{\mathrm{h}}$.

${ }^{\mathrm{c}}$ Estimated from the energy difference, $\Delta E$, at $446 \mathrm{~K}$. 
Table 4

Geometrical parameters and relative energies of the s-cis-trans, s-trans-trans, s-cis-gauche and s-trans-gauche conformers of ethylvanillin obtained from the MP2/6-31G** calculations

\begin{tabular}{|c|c|c|c|c|}
\hline Parameters $^{\mathrm{a}}$ & s-cis-trans & s-trans-trans & s-cis-gauche & s-trans-gauche \\
\hline \multicolumn{5}{|c|}{ Bond lengths / Å } \\
\hline $\mathrm{C}_{1}-\mathrm{C}_{2}$ & 1.406 & 1.405 & 1.406 & 1.405 \\
\hline $\mathrm{C}_{2}-\mathrm{C}_{3}$ & 1.387 & 1.390 & 1.387 & 1.391 \\
\hline $\mathrm{C}_{3}-\mathrm{C}_{4}$ & 1.414 & 1.411 & 1.415 & 1.411 \\
\hline $\mathrm{C}_{4}-\mathrm{C}_{5}$ & 1.391 & 1.394 & 1.391 & 1.394 \\
\hline $\mathrm{C}_{5}-\mathrm{C}_{6}$ & 1.395 & 1.392 & 1.395 & 1.391 \\
\hline $\mathrm{C}_{1}-\mathrm{C}_{6}$ & 1.397 & 1.399 & 1.397 & 1.399 \\
\hline $\mathrm{C}_{1}-\mathrm{C}_{7}$ & 1.472 & 1.474 & 1.472 & 1.474 \\
\hline $\mathrm{C}_{3}-\mathrm{O}_{9}$ & 1.373 & 1.375 & 1.374 & 1.377 \\
\hline $\mathrm{C}_{4}-\mathrm{O}_{12}$ & 1.361 & 1.362 & 1.360 & 1.361 \\
\hline $\mathrm{O}_{9}-\mathrm{C}_{10}$ & 1.435 & 1.433 & 1.439 & 1.437 \\
\hline $\mathrm{C}_{10}-\mathrm{C}_{11}$ & 1.510 & 1.510 & 1.515 & 1.516 \\
\hline $\mathrm{C}_{7}=\mathrm{O}_{8}$ & 1.229 & 1.228 & 1.229 & 1.228 \\
\hline $\mathrm{C}_{7}-\mathrm{H}_{13}$ & 1.106 & 1.107 & 1.106 & 1.108 \\
\hline $\mathrm{C}_{2}-\mathrm{H}_{14}$ & 1.081 & 1.082 & 1.081 & 1.083 \\
\hline $\mathrm{C}_{5}-\mathrm{H}_{21}$ & 1.082 & 1.082 & 1.082 & 1.082 \\
\hline $\mathrm{C}_{6}-\mathrm{H}_{22}$ & 1.084 & 1.082 & 1.084 & 1.082 \\
\hline $\mathrm{C}_{10}-\mathrm{H}_{15}$ & 1.093 & 1.093 & 1.091 & 1.092 \\
\hline $\mathrm{C}_{10}-\mathrm{H}_{16}$ & 1.093 & 1.093 & 1.088 & 1.088 \\
\hline $\mathrm{C}_{11}-\mathrm{H}_{17}$ & 1.089 & 1.089 & 1.090 & 1.090 \\
\hline $\mathrm{C}_{11}-\mathrm{H}_{18}$ & 1.088 & 1.088 & 1.087 & 1.087 \\
\hline
\end{tabular}




$\begin{array}{lllll}\mathrm{C}_{11}-\mathrm{H}_{19} & 1.088 & 1.088 & 1.088 & 1.088 \\ \mathrm{O}_{12}-\mathrm{H}_{20} & 0.970 & 0.970 & 0.970 & 0.970\end{array}$

Bond angles / ${ }^{\circ}$

\begin{tabular}{|c|c|c|c|c|}
\hline $\mathrm{C}_{2}-\mathrm{C}_{1}-\mathrm{C}_{6}$ & 120.7 & 120.6 & 120.8 & 120.7 \\
\hline $\mathrm{C}_{1}-\mathrm{C}_{2}-\mathrm{C}_{3}$ & 118.9 & 119.2 & 119.0 & 119.3 \\
\hline $\mathrm{C}_{2}-\mathrm{C}_{3}-\mathrm{C}_{4}$ & 120.5 & 120.2 & 120.2 & 120.0 \\
\hline $\mathrm{C}_{3}-\mathrm{C}_{4}-\mathrm{C}_{5}$ & 120.2 & 120.2 & 120.4 & 120.3 \\
\hline $\mathrm{C}_{4}-\mathrm{C}_{5}-\mathrm{C}_{6}$ & 119.5 & 119.8 & 119.5 & 119.8 \\
\hline $\mathrm{C}_{1}-\mathrm{C}_{6}-\mathrm{C}_{5}$ & 120.2 & 120.0 & 120.1 & 119.9 \\
\hline $\mathrm{C}_{2}-\mathrm{C}_{1}-\mathrm{C}_{7}$ & 119.2 & 119.1 & 119.1 & 119.1 \\
\hline $\mathrm{C}_{6}-\mathrm{C}_{1}-\mathrm{C}_{7}$ & 120.1 & 120.3 & 120.1 & 120.3 \\
\hline $\mathrm{C}_{1}-\mathrm{C}_{7}=\mathrm{O}_{8}$ & 124.4 & 124.6 & 124.4 & 124.6 \\
\hline $\mathrm{C}_{2}-\mathrm{C}_{3}-\mathrm{O}_{9}$ & 126.6 & 126.6 & 127.1 & 127.1 \\
\hline $\mathrm{C}_{4}-\mathrm{C}_{3}-\mathrm{O}_{9}$ & 113.0 & 113.2 & 112.7 & 112.9 \\
\hline $\mathrm{C}_{3}-\mathrm{C}_{4}-\mathrm{O}_{12}$ & 119.8 & 119.9 & 119.7 & 119.9 \\
\hline $\mathrm{C}_{5}-\mathrm{C}_{4}-\mathrm{O}_{12}$ & 120.0 & 119.9 & 119.9 & 119.8 \\
\hline $\mathrm{C}_{3}-\mathrm{O}_{9}-\mathrm{C}_{10}$ & 116.8 & 117.0 & 117.7 & 117.8 \\
\hline $\mathrm{O}_{9}-\mathrm{C}_{10}-\mathrm{C}_{11}$ & 107.0 & 107.0 & 111.8 & 111.9 \\
\hline $\mathrm{C}_{1}-\mathrm{C}_{7}-\mathrm{H}_{13}$ & 114.9 & 114.8 & 114.9 & 114.8 \\
\hline $\mathrm{O}_{8}=\mathrm{C}_{7}-\mathrm{H}_{13}$ & 120.7 & 120.6 & 120.7 & 120.6 \\
\hline $\mathrm{C}_{1}-\mathrm{C}_{2}-\mathrm{H}_{14}$ & 118.4 & 119.6 & 118.1 & 119.3 \\
\hline $\mathrm{C}_{3}-\mathrm{C}_{2}-\mathrm{H}_{14}$ & 122.7 & 121.3 & 122.9 & 121.4 \\
\hline $\mathrm{C}_{4}-\mathrm{C}_{5}-\mathrm{H}_{21}$ & 118.5 & 118.3 & 118.5 & 118.3 \\
\hline $\mathrm{C}_{6}-\mathrm{C}_{5}-\mathrm{H}_{21}$ & 122.0 & 121.9 & 122.0 & 121.9 \\
\hline $\mathrm{C}_{5}-\mathrm{C}_{6}-\mathrm{H}_{22}$ & 120.0 & 121.3 & 120.1 & 121.3 \\
\hline $\mathrm{C}_{1}-\mathrm{C}_{6}-\mathrm{H}_{22}$ & 119.8 & 118.7 & 119.8 & 118.8 \\
\hline
\end{tabular}




$\begin{array}{lllll}\mathrm{C}_{4}-\mathrm{O}_{12}-\mathrm{H}_{20} & 106.3 & 106.4 & 106.2 & 106.3 \\ \mathrm{O}_{9}-\mathrm{C}_{10}-\mathrm{H}_{15} & 109.2 & 109.3 & 109.4 & 109.6 \\ \mathrm{O}_{9}-\mathrm{C}_{10}-\mathrm{H}_{16} & 109.2 & 109.3 & 104.0 & 104.0 \\ \mathrm{C}_{11}-\mathrm{C}_{10}-\mathrm{H}_{15} & 111.5 & 111.4 & 112.1 & 112.1 \\ \mathrm{C}_{11}-\mathrm{C}_{10}-\mathrm{H}_{16} & 111.5 & 111.4 & 111.1 & 111.0 \\ \mathrm{H}_{15}-\mathrm{C}_{10}-\mathrm{H}_{16} & 108.3 & 108.4 & 108.1 & 107.8 \\ \mathrm{C}_{10}-\mathrm{C}_{11}-\mathrm{H}_{17} & 109.9 & 110.0 & 109.9 & 110.0 \\ \mathrm{C}_{10}-\mathrm{C}_{11}-\mathrm{H}_{18} & 110.4 & 110.3 & 111.3 & 111.3 \\ \mathrm{C}_{10}-\mathrm{C}_{11}-\mathrm{H}_{19} & 110.4 & 110.3 & 109.9 & 109.9 \\ \mathrm{H}_{17}-\mathrm{C}_{11}-\mathrm{H}_{18} & 108.6 & 108.7 & 108.4 & 108.5 \\ \mathrm{H}_{17}-\mathrm{C}_{11}-\mathrm{H}_{19} & 108.6 & 108.7 & 108.6 & 108.6 \\ \mathrm{H}_{18}-\mathrm{C}_{11}-\mathrm{H}_{19} & 108.9 & 108.9 & 108.7 & 108.5\end{array}$

Dihedral angles / ${ }^{\circ}$

$\begin{array}{lllll}\mathrm{C}_{6}-\mathrm{C}_{1}-\mathrm{C}_{2}-\mathrm{C}_{3} & 0.0 & 0.0 & -0.0 & -0.2 \\ \mathrm{C}_{7}-\mathrm{C}_{1}-\mathrm{C}_{2}-\mathrm{C}_{3} & 180.0 & 180.0 & 179.7 & 179.8 \\ \mathrm{C}_{1}-\mathrm{C}_{2}-\mathrm{C}_{3}-\mathrm{C}_{4} & 0.0 & 0.0 & -0.1 & 0.1 \\ \mathrm{C}_{1}-\mathrm{C}_{2}-\mathrm{C}_{3}-\mathrm{O}_{9} & 180.0 & 180.0 & 178.7 & 178.4 \\ \mathrm{C}_{2}-\mathrm{C}_{3}-\mathrm{C}_{4}-\mathrm{C}_{5} & 0.0 & 0.0 & 0.2 & 0.0 \\ \mathrm{C}_{2}-\mathrm{C}_{3}-\mathrm{C}_{4}-\mathrm{O}_{12} & 180.0 & 180.0 & -180.0 & 180.0 \\ \mathrm{O}_{9}-\mathrm{C}_{3}-\mathrm{C}_{4}-\mathrm{C}_{5} & 180.0 & 180.0 & -178.7 & -178.5 \\ \mathrm{O}_{9}-\mathrm{C}_{3}-\mathrm{C}_{4}-\mathrm{O}_{12} & 0.0 & 0.0 & 1.1 & 1.4 \\ \mathrm{C}_{3}-\mathrm{C}_{4}-\mathrm{C}_{5}-\mathrm{C}_{6} & 0.0 & 0.0 & -0.2 & -0.1 \\ \mathrm{O}_{12}-\mathrm{C}_{4}-\mathrm{C}_{5}-\mathrm{C}_{6} & 180.0 & 180.0 & 180.0 & 180.0 \\ \mathrm{C}_{4}-\mathrm{C}_{5}-\mathrm{C}_{6}-\mathrm{C}_{1} & 0.0 & 0.0 & 0.1 & 0.0 \\ \mathrm{C}_{5}-\mathrm{C}_{6}-\mathrm{C}_{1}-\mathrm{C}_{2} & 0.0 & 0.0 & 0.0 & 0.1 \\ \mathrm{C}_{5}-\mathrm{C}_{6}-\mathrm{C}_{1}-\mathrm{C}_{7} & 180.0 & 180.0 & -179.7 & -179.8\end{array}$




\begin{tabular}{|c|c|c|c|c|}
\hline $\mathrm{C}_{2}-\mathrm{C}_{1}-\mathrm{C}_{7}=\mathrm{O}_{8}$ & 0.0 & 180.0 & -0.3 & 179.9 \\
\hline $\mathrm{C}_{6}-\mathrm{C}_{1}-\mathrm{C}_{7}=\mathrm{O}_{8}$ & 180.0 & 0.0 & 179.4 & -0.1 \\
\hline $\mathrm{C}_{2}-\mathrm{C}_{3}-\mathrm{O}_{9}-\mathrm{C}_{10}$ & 0.0 & 0.0 & 7.9 & 11.7 \\
\hline $\mathrm{C}_{4}-\mathrm{C}_{3}-\mathrm{O}_{9}-\mathrm{C}_{10}$ & 180.0 & 180.0 & -173.3 & -169.8 \\
\hline $\mathrm{C}_{3}-\mathrm{O}_{9}-\mathrm{C}_{10}-\mathrm{C}_{11}$ & 180.0 & 180.0 & 75.8 & 73.8 \\
\hline $\mathrm{C}_{2}-\mathrm{C}_{1}-\mathrm{C}_{7}-\mathrm{H}_{13}$ & 180.0 & 0.0 & 179.7 & -0.1 \\
\hline $\mathrm{C}_{6}-\mathrm{C}_{1}-\mathrm{C}_{7}-\mathrm{H}_{13}$ & 0.0 & 180.0 & -0.6 & 179.9 \\
\hline $\mathrm{C}_{6}-\mathrm{C}_{1}-\mathrm{C}_{2}-\mathrm{H}_{14}$ & 180.0 & 180.0 & -180.0 & 179.9 \\
\hline $\mathrm{C}_{7}-\mathrm{C}_{1}-\mathrm{C}_{2}-\mathrm{H}_{14}$ & 0.0 & 0.0 & -0.2 & -0.1 \\
\hline $\mathrm{C}_{4}-\mathrm{C}_{3}-\mathrm{C}_{2}-\mathrm{H}_{14}$ & 180.0 & 180.0 & 179.9 & -180.0 \\
\hline $\mathrm{O}_{9}-\mathrm{C}_{3}-\mathrm{C}_{2}-\mathrm{H}_{14}$ & 0.0 & 0.0 & -1.4 & -1.7 \\
\hline $\mathrm{C}_{3}-\mathrm{O}_{9}-\mathrm{C}_{10}-\mathrm{H}_{15}$ & 59.2 & 59.2 & -49.0 & -51.2 \\
\hline $\mathrm{C}_{3}-\mathrm{O}_{9}-\mathrm{C}_{10}-\mathrm{H}_{16}$ & -59.2 & -59.2 & -164.3 & -166.3 \\
\hline $\mathrm{O}_{9}-\mathrm{C}_{10}-\mathrm{C}_{11}-\mathrm{H}_{17}$ & 180.0 & 180.0 & 177.1 & 177.3 \\
\hline $\mathrm{O}_{9}-\mathrm{C}_{10}-\mathrm{C}_{11}-\mathrm{H}_{18}$ & -60.2 & -60.2 & -62.8 & -62.5 \\
\hline $\mathrm{O}_{9}-\mathrm{C}_{10}-\mathrm{C}_{11}-\mathrm{H}_{19}$ & 60.2 & 60.2 & 57.6 & 57.8 \\
\hline $\mathrm{H}_{15}-\mathrm{C}_{10}-\mathrm{C}_{11}-\mathrm{H}_{17}$ & -60.6 & -60.6 & -59.6 & -59.1 \\
\hline $\mathrm{H}_{15}-\mathrm{C}_{10}-\mathrm{C}_{11}-\mathrm{H}_{18}$ & 59.2 & 59.3 & 60.5 & 61.1 \\
\hline $\mathrm{H}_{15}-\mathrm{C}_{10}-\mathrm{C}_{11}-\mathrm{H}_{19}$ & 179.6 & 179.6 & -179.0 & -178.6 \\
\hline $\mathrm{H}_{16}-\mathrm{C}_{10}-\mathrm{C}_{11}-\mathrm{H}_{17}$ & 60.6 & 60.6 & 61.5 & 61.6 \\
\hline $\mathrm{H}_{16}-\mathrm{C}_{10}-\mathrm{C}_{11}-\mathrm{H}_{18}$ & -179.6 & -179.6 & -178.4 & -178.2 \\
\hline $\mathrm{H}_{16}-\mathrm{C}_{10}-\mathrm{C}_{11}-\mathrm{H}_{19}$ & -59.2 & -59.3 & -58.0 & -57.9 \\
\hline $\mathrm{C}_{3}-\mathrm{C}_{4}-\mathrm{O}_{12}-\mathrm{H}_{20}$ & 0.0 & 0.0 & 0.3 & 0.4 \\
\hline $\mathrm{C}_{5}-\mathrm{C}_{4}-\mathrm{O}_{12}-\mathrm{H}_{20}$ & 180.0 & 180.0 & -179.9 & -179.7 \\
\hline $\mathrm{C}_{3}-\mathrm{C}_{4}-\mathrm{C}_{5}-\mathrm{H}_{21}$ & 180.0 & 180.0 & 179.9 & -180.0 \\
\hline $\mathrm{O}_{12}-\mathrm{C}_{4}-\mathrm{C}_{5}-\mathrm{H}_{21}$ & 0.0 & 0.0 & 0.1 & 0.1 \\
\hline $\mathrm{C}_{1}-\mathrm{C}_{6}-\mathrm{C}_{5}-\mathrm{H}_{21}$ & 180.0 & 180.0 & 179.9 & 179.9 \\
\hline
\end{tabular}




\begin{tabular}{lllll}
$\mathrm{H}_{21}-\mathrm{C}_{5}-\mathrm{C}_{6}-\mathrm{H}_{22}$ & 0.0 & 0.0 & 0.0 & 0.1 \\
$\mathrm{C}_{4}-\mathrm{C}_{5}-\mathrm{C}_{6}-\mathrm{H}_{22}$ & 180.0 & 180.0 & -179.8 & -179.8 \\
$\mathrm{C}_{2}-\mathrm{C}_{1}-\mathrm{C}_{6}-\mathrm{H}_{22}$ & 180.0 & 180.0 & 179.9 & 179.9 \\
$\mathrm{C}_{7}-\mathrm{C}_{1}-\mathrm{C}_{6}-\mathrm{H}_{22}$ & 0.0 & 0.0 & 0.2 & -0.0 \\
& & & & \\
$\Delta E / \mathrm{kJ} \mathrm{mol}^{-1 \mathrm{~b}}$ & 0.000 & 4.731 & 3.339 & 8.382 \\
Abundance $/ \%$ & & & \\
\hline
\end{tabular}

${ }^{a}$ See Fig. 1 for the definitions of the atom numbering.

${ }^{b}$ The absolute energy of the s-cis-trans conformer is $-572.9685873 E_{\mathrm{h}}$.

${ }^{\mathrm{c}}$ Estimated from the energy difference, $\Delta E$, at $419 \mathrm{~K}$. 
Table 5

Structural constraints and independent parameters of vanillin

\begin{tabular}{|c|c|c|}
\hline Parameters & $\mathrm{s}-c i s$ & s-trans \\
\hline \multicolumn{3}{|c|}{ Bond lengths $(\AA)$} \\
\hline $\mathrm{C}_{1}-\mathrm{C}_{2}$ & $r_{1}$ & $r_{1}-0.001$ \\
\hline $\mathrm{C}_{2}-\mathrm{C}_{3}$ & $r_{1}-0.020$ & $r_{1}-0.016$ \\
\hline $\mathrm{C}_{3}-\mathrm{C}_{4}$ & $r_{1}+0.008$ & $r_{1}+0.005$ \\
\hline $\mathrm{C}_{4}-\mathrm{C}_{5}$ & $r_{1}-0.015$ & $r_{1}-0.012$ \\
\hline $\mathrm{C}_{5}-\mathrm{C}_{6}$ & $r_{1}-0.011$ & $r_{1}-0.014$ \\
\hline $\mathrm{C}_{1}-\mathrm{C}_{6}$ & $r_{1}-0.009$ & $r_{1}-0.007$ \\
\hline $\mathrm{C}_{1}-\mathrm{C}_{7}$ & $r_{1}+0.067$ & $r_{1}+0.068$ \\
\hline $\mathrm{C}_{3}-\mathrm{O}_{9}$ & $r_{2}$ & $r_{2}+0.002$ \\
\hline $\mathrm{C}_{4}-\mathrm{O}_{11}$ & $r_{2}-0.013$ & $r_{2}-0.012$ \\
\hline $\mathrm{O}_{9}-\mathrm{C}_{10}$ & $r_{2}+0.054$ & $r_{2}+0.053$ \\
\hline $\mathrm{C}_{7}=\mathrm{O}_{8}$ & $r_{3}$ & $r_{3}-0.001$ \\
\hline $\mathrm{C}_{7}-\mathrm{H}_{12}$ & $r_{4}$ & $r_{4}+0.001$ \\
\hline $\mathrm{C}_{2}-\mathrm{H}_{13}$ & $r_{4}-0.025$ & $r_{4}-0.024$ \\
\hline $\mathrm{C}_{5}-\mathrm{H}_{18}$ & $r_{4}-0.025$ & $r_{4}-0.024$ \\
\hline $\mathrm{C}_{6}-\mathrm{H}_{19}$ & $r_{4}-0.022$ & $r_{4}-0.024$ \\
\hline $\mathrm{C}_{10}-\mathrm{H}_{14}$ & $r_{4}-0.021$ & $r_{4}-0.021$ \\
\hline $\mathrm{C}_{10}-\mathrm{H}_{15,16}$ & $r_{4}-0.016$ & $r_{4}-0.015$ \\
\hline $\mathrm{O}_{11}-\mathrm{H}_{17}$ & $r_{4}-0.136$ & $r_{4}-0.136$ \\
\hline
\end{tabular}

Bond angles $\left({ }^{\circ}\right)$
$\mathrm{C}_{2}-\mathrm{C}_{1}-\mathrm{C}_{6}$
$\theta_{1}$
$\theta_{1}-0.1$
$\mathrm{C}_{1}-\mathrm{C}_{2}-\mathrm{C}_{3}$
$\theta_{1}-1.8$
$\theta_{1}-1.6$ 


$\begin{array}{lll}\mathrm{C}_{1}-\mathrm{C}_{6}-\mathrm{C}_{5} & \theta_{1}-0.5 & \theta_{1}-0.7 \\ \mathrm{C}_{2}-\mathrm{C}_{1}-\mathrm{C}_{7} & \theta_{2} & \theta_{2}-0.1 \\ \mathrm{C}_{1}-\mathrm{C}_{7}=\mathrm{C}_{8} & \theta_{3} & \theta_{3}+0.2 \\ \mathrm{C}_{4}-\mathrm{C}_{3}-\mathrm{O}_{9} & \theta_{4} & \theta_{4}+0.2 \\ \mathrm{C}_{3}-\mathrm{C}_{4}-\mathrm{O}_{11} & \theta_{4}+6.9 & \theta_{4}+7.0 \\ \mathrm{C}_{3}-\mathrm{O}_{9}-\mathrm{C}_{10} & \theta_{5} & \theta_{5}+0.2 \\ \mathrm{C}_{1}-\mathrm{C}_{7}-\mathrm{H}_{12} & 115.1 & 115.1 \\ \mathrm{C}_{1}-\mathrm{C}_{2}-\mathrm{H}_{13} & 180.0-0.5\left(\mathrm{C}_{1}-\mathrm{C}_{2}-\mathrm{C}_{3}\right) & 180.0-0.5\left(\mathrm{C}_{1}-\mathrm{C}_{2}-\mathrm{C}_{3}\right) \\ \mathrm{O}_{9}-\mathrm{C}_{10}-\mathrm{H}_{14} & 105.7 & 105.7 \\ \mathrm{O}_{9}-\mathrm{C}_{10}-\mathrm{H}_{15}, 16 & 110.8 & 110.9 \\ \mathrm{C}_{4}-\mathrm{O}_{11}-\mathrm{H}_{17} & 106.4 & 106.4 \\ \mathrm{C}_{4}-\mathrm{C}_{5}-\mathrm{H}_{18} & 180.0-0.5\left(\mathrm{C}_{4}-\mathrm{C}_{5}-\mathrm{C}_{6}\right) & 180.0-0.5\left(\mathrm{C}_{4}-\mathrm{C}_{5}-\mathrm{C}_{6}\right) \\ \mathrm{C}_{5}-\mathrm{C}_{6}-\mathrm{H}_{19} & 180.0-0.5\left(\mathrm{C}_{1}-\mathrm{C}_{6}-\mathrm{C}_{5}\right) & 180.0-0.5\left(\mathrm{C}_{1}-\mathrm{C}_{6}-\mathrm{C}_{5}\right)\end{array}$

Dihedral angles $\left(^{\circ}\right)$

\begin{tabular}{llc}
$\mathrm{C}_{2}-\mathrm{C}_{1}-\mathrm{C}_{7}=\mathrm{C}_{8}$ & 0.0 & 180.0 \\
$\mathrm{C}_{3}-\mathrm{O}_{9}-\mathrm{C}_{10}-\mathrm{H}_{15}$ & 60.9 & 61.0 \\
$\mathrm{C}_{3}-\mathrm{O}_{9}-\mathrm{C}_{10}-\mathrm{H}_{16}$ & -60.9 & -61.0 \\
\hline
\end{tabular}

See Fig. 1 for the atom numbering and the definitions of the conformers. 
Table 6

Structural constraints and independent parameters of isovanillin

\begin{tabular}{|c|c|c|}
\hline Parameters & $\mathrm{s}-\mathrm{cis}$ & s-trans \\
\hline \multicolumn{3}{|c|}{ Bond lengths $(\AA)$} \\
\hline $\mathrm{C}_{1}-\mathrm{C}_{2}$ & $r_{1}$ & $r_{1}-0.001$ \\
\hline $\mathrm{C}_{2}-\mathrm{C}_{3}$ & $r_{1}-0.018$ & $r_{1}-0.015$ \\
\hline $\mathrm{C}_{3}-\mathrm{C}_{4}$ & $r_{1}+0.011$ & $r_{1}+0.007$ \\
\hline $\mathrm{C}_{4}-\mathrm{C}_{5}$ & $r_{1}-0.010$ & $r_{1}-0.007$ \\
\hline $\mathrm{C}_{5}-\mathrm{C}_{6}$ & $r_{1}-0.006$ & $r_{1}-0.009$ \\
\hline $\mathrm{C}_{1}-\mathrm{C}_{6}$ & $r_{1}-0.006$ & $r_{1}-0.005$ \\
\hline $\mathrm{C}_{1}-\mathrm{C}_{7}$ & $r_{1}+0.072$ & $r_{1}+0.073$ \\
\hline $\mathrm{C}_{3}-\mathrm{O}_{9}$ & $r_{2}$ & $r_{2}+0.001$ \\
\hline $\mathrm{C}_{4}-\mathrm{O}_{10}$ & $r_{2}+0.011$ & $r_{2}+0.012$ \\
\hline $\mathrm{O}_{10}-\mathrm{C}_{11}$ & $r_{2}+0.064$ & $r_{2}+0.065$ \\
\hline $\mathrm{C}_{7}=\mathrm{O}_{8}$ & $r_{3}$ & $r_{3}+0.000$ \\
\hline $\mathrm{C}_{7}-\mathrm{H}_{12}$ & $r_{4}$ & $r_{4}-0.000$ \\
\hline $\mathrm{C}_{2}-\mathrm{H}_{13}$ & $r_{4}-0.025$ & $r_{4}-0.023$ \\
\hline $\mathrm{C}_{5}-\mathrm{H}_{18}$ & $r_{4}-0.026$ & $r_{4}-0.026$ \\
\hline $\mathrm{C}_{6}-\mathrm{H}_{19}$ & $r_{4}-0.023$ & $r_{4}-0.025$ \\
\hline $\mathrm{C}_{11}-\mathrm{H}_{15}$ & $r_{4}-0.022$ & $r_{4}-0.022$ \\
\hline $\mathrm{C}_{11}-\mathrm{H}_{16,17}$ & $r_{4}-0.016$ & $r_{4}-0.016$ \\
\hline $\mathrm{O}_{9}-\mathrm{H}_{14}$ & $r_{4}-0.137$ & $r_{4}-0.137$ \\
\hline
\end{tabular}

Bond angles $\left({ }^{\circ}\right)$
$\mathrm{C}_{2}-\mathrm{C}_{1}-\mathrm{C}_{6}$
$\theta_{1}$
$\theta_{1}-0.1$
$\mathrm{C}_{1}-\mathrm{C}_{2}-\mathrm{C}_{3}$
$\theta_{1}-1.2$
$\theta_{1}-1.0$ 


$\begin{array}{lll}\mathrm{C}_{1}-\mathrm{C}_{6}-\mathrm{C}_{5} & \theta_{1}-0.4 & \theta_{1}-0.6 \\ \mathrm{C}_{2}-\mathrm{C}_{1}-\mathrm{C}_{7} & \theta_{2} & \theta_{2}-0.3 \\ \mathrm{C}_{1}-\mathrm{C}_{7}=\mathrm{O}_{8} & \theta_{3} & \theta_{3}-0.1 \\ \mathrm{C}_{4}-\mathrm{C}_{3}-\mathrm{O}_{9} & \theta_{4} & \theta_{4}+0.3 \\ \mathrm{C}_{3}-\mathrm{C}_{4}-\mathrm{O}_{10} & \theta_{4}-6.8 & \theta_{4}-6.7 \\ \mathrm{C}_{4}-\mathrm{O}_{10}-\mathrm{C}_{11} & \theta_{5} & \theta_{5}-0.0 \\ \mathrm{C}_{1}-\mathrm{C}_{7}-\mathrm{H}_{12} & 115.1 & 115.1 \\ \mathrm{C}_{1}-\mathrm{C}_{2}-\mathrm{H}_{13} & 180.0-0.5\left(\mathrm{C}_{1}-\mathrm{C}_{2}-\mathrm{C}_{3}\right) & 180.0-0.5\left(\mathrm{C}_{1}-\mathrm{C}_{2}-\mathrm{C}_{3}\right) \\ \mathrm{C}_{3}-\mathrm{O}_{9}-\mathrm{H}_{14} & 106.4 & 106.4 \\ \mathrm{O}_{10}-\mathrm{C}_{11}-\mathrm{H}_{15} & 105.7 & 105.6 \\ \mathrm{O}_{10}-\mathrm{C}_{11}-\mathrm{H}_{16,17} & 110.9 & 110.9 \\ \mathrm{C}_{4}-\mathrm{C}_{5}-\mathrm{H}_{18} & 180.0-0.5\left(\mathrm{C}_{4}-\mathrm{C}_{5}-\mathrm{C}_{6}\right) & 180.0-0.5\left(\mathrm{C}_{4}-\mathrm{C}_{5}-\mathrm{C}_{6}\right) \\ \mathrm{C}_{5}-\mathrm{C}_{6}-\mathrm{H}_{19} & 180.0-0.5\left(\mathrm{C}_{1}-\mathrm{C}_{6}-\mathrm{C}_{5}\right) & 180.0-0.5\left(\mathrm{C}_{1}-\mathrm{C}_{6}-\mathrm{C}_{5}\right)\end{array}$

Dihedral angles $\left(^{\circ}\right)$
$\mathrm{C}_{2}-\mathrm{C}_{1}-\mathrm{C}_{7}=\mathrm{C}_{8}$
0.0
180.0
$\mathrm{C}_{4}-\mathrm{O}_{10}-\mathrm{C}_{11}-\mathrm{H}_{16}$
$-61.0$
$-61.1$
$\mathrm{C}_{4}-\mathrm{O}_{10}-\mathrm{C}_{11}-\mathrm{H}_{17}$
61.0
61.1

See Fig. 1 for the atom numbering and the definitions of the conformers. 
Table 7

Structural constraints and independent parameters of ethylvanillin

\begin{tabular}{|c|c|c|c|c|}
\hline Parameters & s-cis-trans & s-trans-trans & s-cis-gauche & s-trans-gau \\
\hline \multicolumn{5}{|c|}{ Bond lengths $(\AA)$} \\
\hline $\mathrm{C}_{1}-\mathrm{C}_{2}$ & $r_{1}$ & $r_{1}-0.001$ & $r_{1}-0.000$ & $r_{1}-0.001$ \\
\hline $\mathrm{C}_{2}-\mathrm{C}_{3}$ & $r_{1}-0.019$ & $r_{1}-0.016$ & $r_{1}-0.019$ & $r_{1}-0.015$ \\
\hline $\mathrm{C}_{3}-\mathrm{C}_{4}$ & $r_{1}+0.008$ & $r_{1}+0.005$ & $r_{1}+0.009$ & $r_{1}+0.005$ \\
\hline $\mathrm{C}_{4}-\mathrm{C}_{5}$ & $r_{1}-0.015$ & $r_{1}-0.012$ & $r_{1}-0.014$ & $r_{1}-0.012$ \\
\hline $\mathrm{C}_{5}-\mathrm{C}_{6}$ & $r_{1}-0.010$ & $r_{1}-0.014$ & $r_{1}-0.011$ & $r_{1}-0.015$ \\
\hline $\mathrm{C}_{1}-\mathrm{C}_{6}$ & $r_{1}-0.009$ & $r_{1}-0.007$ & $r_{1}-0.009$ & $r_{1}-0.007$ \\
\hline $\mathrm{C}_{1}-\mathrm{C}_{7}$ & $r_{1}+0.066$ & $r_{1}+0.068$ & $r_{1}+0.067$ & $r_{1}+0.068$ \\
\hline $\mathrm{C}_{3}-\mathrm{O}_{9}$ & $r_{2}$ & $r_{2}+0.002$ & $r_{2}+0.001$ & $r_{2}+0.003$ \\
\hline $\mathrm{C}_{4}-\mathrm{O}_{12}$ & $r_{2}-0.012$ & $r_{2}-0.012$ & $r_{2}-0.013$ & $r_{2}-0.012$ \\
\hline $\mathrm{O}_{9}-\mathrm{C}_{10}$ & $r_{2}+0.062$ & $r_{2}+0.060$ & $r_{2}+0.066$ & $r_{2}+0.064$ \\
\hline $\mathrm{C}_{10}-\mathrm{C}_{11}$ & $r_{3}$ & $r_{3}+0.000$ & $r_{3}+0.005$ & $r_{3}+0.006$ \\
\hline $\mathrm{C}_{7}=\mathrm{O}_{8}$ & $r_{4}$ & $r_{4}-0.001$ & $r_{4}-0.000$ & $r_{4}-0.001$ \\
\hline $\mathrm{C}_{7}-\mathrm{H}_{13}$ & $r_{5}$ & $r_{5}+0.001$ & $r_{5}$ & $r_{5}+0.001$ \\
\hline $\mathrm{C}_{2}-\mathrm{H}_{14}$ & $r_{5}-0.025$ & $r_{5}-0.024$ & $r_{5}-0.025$ & $r_{5}-0.024$ \\
\hline $\mathrm{C}_{5}-\mathrm{H}_{21}$ & $r_{5}-0.025$ & $r_{5}-0.024$ & $r_{5}-0.025$ & $r_{5}-0.024$ \\
\hline $\mathrm{C}_{6}-\mathrm{H}_{22}$ & $r_{5}-0.022$ & $r_{5}-0.024$ & $r_{5}-0.022$ & $r_{5}-0.024$ \\
\hline $\mathrm{C}_{10}-\mathrm{H}_{15}$ & $r_{5}-0.013$ & $r_{5}-0.013$ & $r_{5}-0.015$ & $r_{5}-0.014$ \\
\hline $\mathrm{C}_{10}-\mathrm{H}_{16}$ & $r_{5}-0.013$ & $r_{5}-0.013$ & $r_{5}-0.018$ & $r_{5}-0.018$ \\
\hline $\mathrm{C}_{11}-\mathrm{H}_{17}$ & $r_{5}-0.017$ & $r_{5}-0.017$ & $r_{5}-0.017$ & $r_{5}-0.017$ \\
\hline $\mathrm{C}_{11}-\mathrm{H}_{18}$ & $r_{5}-0.019$ & $r_{5}-0.019$ & $r_{5}-0.019$ & $r_{5}-0.019$ \\
\hline $\mathrm{C}_{11}-\mathrm{H}_{19}$ & $r_{5}-0.019$ & $r_{5}-0.019$ & $r_{5}-0.018$ & $r_{5}-0.018$ \\
\hline $\mathrm{O}_{12}-\mathrm{H}_{20}$ & $r_{5}-0.136$ & $r_{5}-0.136$ & $r_{5}-0.136$ & $r_{5}-0.136$ \\
\hline
\end{tabular}


Bond angles $\left(^{\circ}\right)$

$\begin{array}{lllll}\mathrm{C}_{2}-\mathrm{C}_{1}-\mathrm{C}_{6} & \theta_{1} & \theta_{1}-0.1 & \theta_{1}+0.1 & \theta_{1}-0.1 \\ \mathrm{C}_{1}-\mathrm{C}_{2}-\mathrm{C}_{3} & \theta_{1}-1.8 & \theta_{1}-1.6 & \theta_{1}-1.7 & \theta_{1}-1.4 \\ \mathrm{C}_{1}-\mathrm{C}_{6}-\mathrm{C}_{5} & \theta_{1}-0.5 & \theta_{1}-0.7 & \theta_{1}-0.6 & \theta_{1}-0.8 \\ \mathrm{C}_{2}-\mathrm{C}_{1}-\mathrm{C}_{7} & \theta_{2} & \theta_{2}-0.1 & \theta_{2}-0.1 & \theta_{2}-0.1 \\ \mathrm{C}_{1}-\mathrm{C}_{7}=\mathrm{O}_{8} & \theta_{3} & \theta_{3}+0.2 & \theta_{3}-0.0 & \theta_{3}+0.2 \\ \mathrm{C}_{4}-\mathrm{C}_{3}-\mathrm{O}_{9} & \theta_{4} & \theta_{4}+0.2 & \theta_{4}-0.3 & \theta_{4}-0.1 \\ \mathrm{C}_{3}-\mathrm{C}_{4}-\mathrm{O}_{12} & \theta_{4}+6.8 & \theta_{4}+6.9 & \theta_{4}+6.7 & \theta_{4}+6.9 \\ \mathrm{C}_{3}-\mathrm{O}_{9}-\mathrm{C}_{10} & \theta_{5} & \theta_{5}+0.2 & \theta_{5}+0.9 & \theta_{5}+1.0 \\ \mathrm{O}_{9}-\mathrm{C}_{10}-\mathrm{C}_{11} & \theta_{6} & \theta_{6}+0.0 & \theta_{6}+4.8 & \theta_{6}+5.0 \\ \mathrm{C}_{1}-\mathrm{C}_{7}-\mathrm{H}_{13} & 115.1 & 115.1 & 115.1 & 115.1 \\ \mathrm{C}_{1}-\mathrm{C}_{2}-\mathrm{H}_{14} & 180.0-0.5 & 180.0-0.5 & 180.0-0.5 & 180.0-0.5 \\ & \left(\mathrm{C}_{1}-\mathrm{C}_{2}-\mathrm{C}_{3}\right) & \left(\mathrm{C}_{1}-\mathrm{C}_{2}-\mathrm{C}_{3}\right) & \left(\mathrm{C}_{1}-\mathrm{C}_{2}-\mathrm{C}_{3}\right) & \left(\mathrm{C}_{1}-\mathrm{C}_{2}-\mathrm{C}_{3}\right) \\ \mathrm{O}_{9}-\mathrm{C}_{10}-\mathrm{H}_{15} & 109.2 & 109.3 & 109.4 & 109.6 \\ \mathrm{O}_{9}-\mathrm{C}_{10}-\mathrm{H}_{16} & 109.2 & 109.3 & 104.0 & 104.0 \\ \mathrm{C}_{10}-\mathrm{C}_{11}-\mathrm{H}_{17} & 109.9 & 110.0 & 109.9 & 110.0 \\ \mathrm{C}_{10}-\mathrm{C}_{11}-\mathrm{H}_{18} & 110.4 & 110.3 & 111.3 & 111.3 \\ \mathrm{C}_{10}-\mathrm{C}_{11}-\mathrm{H}_{19} & 110.4 & 110.3 & 109.9 & 109.9 \\ \mathrm{C}_{4}-\mathrm{O}_{12}-\mathrm{H}_{20} & 106.4 & 106.4 & 106.4 & 106.4 \\ \mathrm{C}_{4}-\mathrm{C}_{5}-\mathrm{H}_{21} & 180.0-0.5 & 180.0-0.5 & 180.0-0.5 & 180.0-0.5 \\ \mathrm{C}_{5}-\mathrm{C}_{6}-\mathrm{H}_{22} & \left(\mathrm{C}_{4}-\mathrm{C}_{5}-\mathrm{C}_{6}\right) & \left(\mathrm{C}_{4}-\mathrm{C}_{5}-\mathrm{C}_{6}\right) & \left(\mathrm{C}_{4}-\mathrm{C}_{5}-\mathrm{C}_{6}\right) & \left(\mathrm{C}_{4}-\mathrm{C}_{5}-\mathrm{C}_{6}\right) \\ & 180.0-0.5 & 180.0-0.5 & 180.0-0.5 & 180.0-0.5 \\ & \left(\mathrm{C}_{1}-\mathrm{C}_{6}-\mathrm{C}_{5}\right) & \left(\mathrm{C}_{1}-\mathrm{C}_{6}-\mathrm{C}_{5}\right) & \left(\mathrm{C}_{1}-\mathrm{C}_{6}-\mathrm{C}_{5}\right)\end{array}$

Dihedral angles $\left(^{\circ}\right)$

$\begin{array}{lllll}\mathrm{C}_{2}-\mathrm{C}_{1}-\mathrm{C}_{7}=\mathrm{C}_{8} & 0.0 & 180.0 & 0.0 & 180.0\end{array}$ 


\begin{tabular}{lllll}
$\mathrm{C}_{2}-\mathrm{C}_{3}-\mathrm{O}_{9}-\mathrm{C}_{10}$ & 0.0 & 0.0 & 7.9 & 11.7 \\
$\mathrm{C}_{3}-\mathrm{O}_{9}-\mathrm{C}_{10}-\mathrm{C}_{11}$ & 180.0 & 180.0 & 75.8 & 73.8 \\
$\mathrm{C}_{3}-\mathrm{O}_{9}-\mathrm{C}_{10}-\mathrm{H}_{15}$ & 59.2 & 59.2 & -49.0 & -51.2 \\
$\mathrm{C}_{3}-\mathrm{O}_{9}-\mathrm{C}_{10}-\mathrm{H}_{16}$ & -59.2 & -59.2 & -164.3 & -166.3 \\
$\mathrm{O}_{9}-\mathrm{C}_{10}-\mathrm{C}_{11}-\mathrm{H}_{17}$ & 180.0 & 180.0 & 177.1 & 177.3 \\
$\mathrm{O}_{9}-\mathrm{C}_{10}-\mathrm{C}_{11}-\mathrm{H}_{18}$ & -60.2 & -60.2 & -62.8 & -62.5 \\
$\mathrm{O}_{9}-\mathrm{C}_{10}-\mathrm{C}_{11}-\mathrm{H}_{19}$ & 60.2 & 60.2 & 57.6 & 57.8 \\
\hline
\end{tabular}

See Fig. 1 for the atom numbering and the definitions of the conformers. 
Table 8

Molecular structures of vanillin, isovanillin and ethylvanillin

\begin{tabular}{|c|c|c|c|c|c|c|c|c|c|c|c|c|}
\hline \multirow[t]{2}{*}{ Parameters ${ }^{\text {a }}$} & \multicolumn{4}{|c|}{ Vanillin (s-cis) } & \multicolumn{4}{|c|}{ Isovanillin (s-cis) } & \multicolumn{4}{|c|}{ Ethylvanillin (s-cis-trans) } \\
\hline & $\mathrm{ED}\left(r_{\mathrm{g}}\right.$ & and $\angle_{\alpha}$ ) & MP2 & DFT $^{d}$ & $\mathrm{ED}\left(r_{\mathrm{g}}\right.$ & $\mathrm{nd} \angle \alpha)$ & MP2 & DFT $^{d}$ & $\mathrm{ED}\left(r_{\mathrm{g}}\right.$ & and $\angle_{\alpha}$ ) & MP2 & DFT $^{d}$ \\
\hline \multicolumn{13}{|c|}{ Bond lengths $(\AA)$} \\
\hline $\mathrm{C}_{1}-\mathrm{C}_{2}$ & 1.405 & ) & 1.406 & 1.410 & 1.407 & 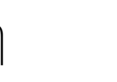 & 1.403 & 1.406 & 1.405 & ) & 1.406 & 1.410 \\
\hline $\mathrm{C}_{2}-\mathrm{C}_{3}$ & 1.385 & 1 & 1.386 & 1.382 & 1.388 & | & 1.385 & 1.384 & 1.385 & | & 1.387 & 1.383 \\
\hline $\mathrm{C}_{3}-\mathrm{C}_{4}$ & 1.413 & $\mid$ & 1.414 & 1.418 & 1.418 & | & 1.414 & 1.417 & 1.413 & | & 1.414 & 1.418 \\
\hline $\mathrm{C}_{4}-\mathrm{C}_{5}$ & 1.390 & $\zeta(4)$ & 1.391 & 1.393 & 1.397 & $(4)$ & 1.394 & 1.394 & 1.390 & \}$(6)$ & 1.391 & 1.393 \\
\hline $\mathrm{C}_{5}-\mathrm{C}_{6}$ & 1.394 & | & 1.395 & 1.394 & 1.401 & | & 1.398 & 1.397 & 1.394 & | & 1.395 & 1.394 \\
\hline $\mathrm{C}_{1}-\mathrm{C}_{6}$ & 1.396 & $\mid$ & 1.397 & 1.398 & 1.400 & | & 1.397 & 1.397 & 1.396 & | & 1.397 & 1.398 \\
\hline$<\mathrm{C}-\mathrm{C}>_{\text {ring }}$ & 1.397 & $\mid$ & 1.398 & 1.399 & 1.402 & | & 1.398 & 1.399 & 1.397 & | & 1.398 & 1.399 \\
\hline $\mathrm{C}_{1}-\mathrm{C}_{7}$ & 1.471 & J & 1.472 & 1.471 & 1.479 & 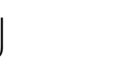 & 1.475 & 1.475 & 1.471 & J & 1.472 & 1.471 \\
\hline $\mathrm{C}_{\text {ring }}-\mathrm{O}_{\mathrm{Me} / \mathrm{Et}}$ & 1.374 & 1 & 1.373 & 1.372 & 1.369 & 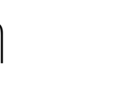 & 1.373 & 1.368 & 1.365 & ) & 1.373 & 1.371 \\
\hline $\mathrm{C}_{\text {ring }}-\mathrm{O}_{\mathrm{H}}$ & 1.361 & \}$(9)$ & 1.361 & 1.354 & 1.357 & (9) & 1.362 & 1.359 & 1.352 & $\zeta(13)$ & 1.361 & 1.354 \\
\hline $\mathrm{O}-\mathrm{C}_{\mathrm{Me} / \mathrm{Et}}$ & 1.428 & $J$ & 1.428 & 1.423 & 1.422 & & 1.427 & 1.423 & 1.427 & J & 1.435 & 1.433 \\
\hline
\end{tabular}


$\mathrm{C}-\mathrm{C}_{\mathrm{Et}}$

\begin{tabular}{|c|c|c|c|}
\hline $\mathrm{C}_{7}=\mathrm{O}_{8}$ & 1.214 & (8) & 1.229 \\
\hline$<\mathrm{C}-\mathrm{H}>$ & 1.110 & & 1.088 \\
\hline $\mathrm{O}-\mathrm{H}$ & 0.991 & & 0.970 \\
\hline
\end{tabular}

Bond angles $\left({ }^{\circ}\right)$

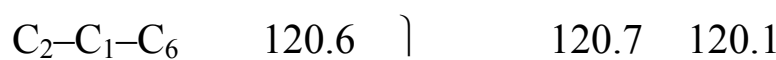

$\begin{array}{lllll}\mathrm{C}_{1}-\mathrm{C}_{2}-\mathrm{C}_{3} & 118.8 & \zeta(2) & 118.9 & 119.5\end{array}$

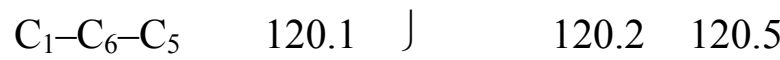

$\mathrm{C}_{2}-\mathrm{C}_{3}-\mathrm{C}_{4} \quad 120.9 \quad{ }^{\mathrm{e}} \quad 120.5 \quad 120.2$

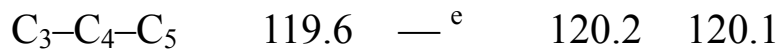

$\mathrm{C}_{4}-\mathrm{C}_{5}-\mathrm{C}_{6} \quad 120.0 \quad$ e $^{\mathrm{e}} \quad 119.5 \quad 119.5$

$\begin{array}{ccccc}\mathrm{C}_{2}-\mathrm{C}_{1}-\mathrm{C}_{7} & 122.7 & \text { (18) } & 119.2 & 119.5\end{array}$

$\mathrm{C}_{1}-\mathrm{C}_{7}=\mathrm{O}_{8} \quad 119.4 \quad(16) \quad 124.4 \quad 124.9$
$1.494 \quad(21) \quad 1.510 \quad 1.517$

$\begin{array}{llll}1.221 & (9) & 1.228 & 1.217\end{array}$

$\begin{array}{llll}1.206 & (9) & 1.229 & 1.219\end{array}$

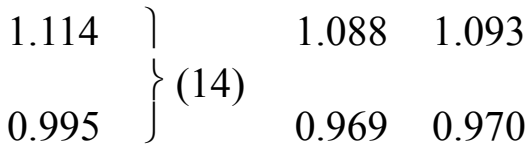

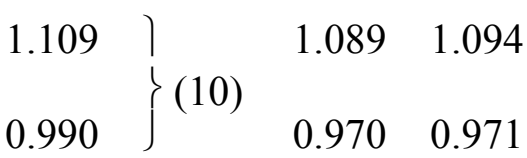

\begin{tabular}{|c|c|c|c|c|c|c|c|}
\hline 120.2 & ) & 120.7 & 120.2 & 120.2 & ) & 120.7 & 120.1 \\
\hline 119.0 & \}$(3)$ & 119.4 & 119.9 & 118.4 & \}$(3)$ & 118.9 & 119.6 \\
\hline 119.9 & $J$ & 120.3 & 120.4 & 119.7 & J & 120.2 & 120.5 \\
\hline 121.9 & $-^{\mathrm{e}}$ & 119.9 & 119.6 & 122.8 & $-^{\mathrm{e}}$ & 120.5 & 120.1 \\
\hline 117.8 & $-^{\mathrm{e}}$ & 120.8 & 120.7 & 116.8 & $-^{\mathrm{e}}$ & 120.2 & 120.2 \\
\hline 121.2 & $-^{\mathrm{e}}$ & 119.0 & 119.3 & 122.0 & $-^{\mathrm{e}}$ & 119.5 & 119.5 \\
\hline 124.6 & (25) & 119.8 & 120.1 & 121.7 & (21) & 119.2 & 119.6 \\
\hline 121.3 & (24) & 124.5 & 125.0 & 128.8 & (22) & 124.4 & 24.9 \\
\hline
\end{tabular}




\begin{tabular}{|c|c|c|c|c|c|c|c|c|c|c|c|c|}
\hline $\mathrm{C}-\mathrm{C}_{\text {ring }}-\mathrm{O}_{\mathrm{Me} / \mathrm{Et}}$ & 112.2 & & 113.0 & 113.2 & 114.4 & & 113.0 & 113.4 & 112.8 & & 113.0 & 113.2 \\
\hline $\mathrm{C}-\mathrm{C}_{\text {ring }}-\mathrm{O}_{\mathrm{H}}{ }^{\mathrm{g}}$ & 119.1 & $(12)$ & 119.9 & 119.7 & 121.2 & $(12)$ & 119.8 & 119.9 & 119.6 & (14) & 119.8 & 119.6 \\
\hline $\mathrm{C}_{\text {ring }}-\mathrm{O}-\mathrm{C}_{\mathrm{Me} / \mathrm{Et}}$ & 121.7 & $(29)$ & 116.3 & 117.9 & 123.8 & (26) & 116.8 & 118.6 & 115.1 & (27) & 116.8 & 118.4 \\
\hline $\mathrm{O}-\mathrm{C}-\mathrm{C}_{\mathrm{Et}}$ & & & & & & & & & 102.7 & (28) & 107.0 & 107.8 \\
\hline $\mathrm{C}_{1}-\mathrm{C}_{7}-\mathrm{H}$ & 115.1 & $-^{h}$ & 114.9 & 114.4 & 115.1 & $-^{\mathrm{h}}$ & 114.8 & 114.3 & 115.1 & $-^{\mathrm{h}}$ & 114.9 & 114.4 \\
\hline $\mathrm{C}_{\text {ring }}-\mathrm{O}-\mathrm{H}$ & 106.4 & $-^{h}$ & 106.5 & 107.2 & 106.4 & $-^{\mathrm{h}}$ & 106.7 & 107.4 & 106.4 & $-^{\mathrm{h}}$ & 106.3 & 107.1 \\
\hline
\end{tabular}

${ }^{a}$ See Fig. 1 for the atom numbering. Angle brackets denote average values.

${ }^{\mathrm{b}}$ Values in parentheses are estimated error limits $(3 \sigma)$ referring to the last significant digit.

${ }^{\mathrm{c}} r_{\mathrm{e}}$ structure obtained from the MP2/6-31G** calculation.

${ }^{\mathrm{d}} r_{\mathrm{e}}$ structure obtained from the B3LYP/6-31G** calculation.

${ }^{\mathrm{e}}$ Dependent parameter.

${ }^{\mathrm{f}} \mathrm{C}_{4}-\mathrm{C}_{3}-\mathrm{O}_{9}$ angle for vanillin and ethylvanillin, and $\mathrm{C}_{3}-\mathrm{C}_{4}-\mathrm{O}_{10}$ angle for isovanillin.

${ }^{\mathrm{g}} \mathrm{C}_{3}-\mathrm{C}_{4}-\mathrm{O}_{11}$ angle for vanillin, $\mathrm{C}_{4}-\mathrm{C}_{3}-\mathrm{O}_{9}$ angle for isovanillin and $\mathrm{C}_{3}-\mathrm{C}_{4}-\mathrm{O}_{12}$ angle for ethylvanillin.

${ }^{\mathrm{h}}$ Assumed. 
Table 9

Comparison of the gas-phase and crystalline structures of vanillin and isovanillin

\begin{tabular}{|c|c|c|c|c|c|c|}
\hline \multirow[t]{2}{*}{ Parameters ${ }^{\mathrm{a}}$} & \multicolumn{3}{|c|}{ Vanillin (s-cis) } & \multicolumn{3}{|c|}{ Isovanillin (s-trans) } \\
\hline & $\mathrm{ED}\left(r_{\mathrm{g}}\right.$ & and $\angle_{\alpha}$ ) & X-ray ${ }^{c}$ & $\mathrm{ED}\left(r_{\mathrm{g}}\right.$ & and $\left.\angle_{\alpha}\right)^{\mathrm{b}}$ & X-ray ${ }^{\mathrm{d}}$ \\
\hline \multicolumn{7}{|c|}{ Bond lengths $(\AA)$} \\
\hline $\mathrm{C}_{1}-\mathrm{C}_{2}$ & 1.405 & १ & $1.400(3)$ & 1.406 & १ & $1.396(6)$ \\
\hline $\mathrm{C}_{2}-\mathrm{C}_{3}$ & 1.385 & $\mid$ & $1.370(3)$ & 1.391 & | & $1.377(6)$ \\
\hline $\mathrm{C}_{3}-\mathrm{C}_{4}$ & 1.413 & | & $1.403(3)$ & 1.414 & | & $1.399(6)$ \\
\hline $\mathrm{C}_{4}-\mathrm{C}_{5}$ & 1.390 & $\zeta(4)$ & $1.381(3)$ & 1.400 & \}$(4)$ & $1.385(6)$ \\
\hline $\mathrm{C}_{5}-\mathrm{C}_{6}$ & 1.394 & | & $1.378(4)$ & 1.398 & | & $1.385(6)$ \\
\hline $\mathrm{C}_{1}-\mathrm{C}_{6}$ & 1.396 & | & $1.379(3)$ & 1.402 & | & $1.385(6)$ \\
\hline $\mathrm{C}_{1}-\mathrm{C}_{7}$ & 1.471 & J & $1.459(3)$ & 1.480 & J & $1.463(6)$ \\
\hline $\mathrm{C}_{\text {ring }}-\mathrm{O}_{\mathrm{Me}}$ & 1.374 & १ & $1.360(2)$ & 1.369 & १ & $1.365(6)$ \\
\hline $\mathrm{C}_{\text {ring }}-\mathrm{O}_{\mathrm{H}}$ & 1.361 & \}$(9)$ & $1.348(3)$ & 1.358 & $\zeta(9)$ & $1.358(6)$ \\
\hline $\mathrm{O}-\mathrm{C}_{\mathrm{Me}}$ & 1.428 & J & $1.430(3)$ & 1.422 & J & $1.428(6)$ \\
\hline $\mathrm{C}_{7}=\mathrm{O}_{8}$ & 1.214 & (8) & $1.205(3)$ & 1.221 & (9) & $1.212(6)$ \\
\hline
\end{tabular}

Bond angles $\left(^{\circ}\right.$ )

\begin{tabular}{|c|c|c|c|c|c|c|}
\hline $\mathrm{C}_{2}-\mathrm{C}_{1}-\mathrm{C}_{6}$ & 120.6 & 1 & $119.6(2)$ & 120.1 & $\uparrow$ & $119.5(5)$ \\
\hline $\mathrm{C}_{1}-\mathrm{C}_{2}-\mathrm{C}_{3}$ & 118.8 & $\zeta(2)$ & $120.2(2)$ & 119.3 & \}$(3)$ & $121.0(5)$ \\
\hline $\mathrm{C}_{1}-\mathrm{C}_{6}-\mathrm{C}_{5}$ & 120.1 & J & $120.6(2)$ & 119.7 & J & $120.1(5)$ \\
\hline $\mathrm{C}_{2}-\mathrm{C}_{3}-\mathrm{C}_{4}$ & 120.9 & $-^{\mathrm{e}}$ & $119.8(2)$ & 121.7 & $-^{e}$ & $118.9(5)$ \\
\hline $\mathrm{C}_{3}-\mathrm{C}_{4}-\mathrm{C}_{5}$ & 119.6 & $-^{\mathrm{e}}$ & $119.9(2)$ & 117.7 & $-^{\mathrm{e}}$ & $120.5(5)$ \\
\hline $\mathrm{C}_{4}-\mathrm{C}_{5}-\mathrm{C}_{6}$ & 120.0 & $-^{\mathrm{e}}$ & $120.0(2)$ & 121.5 & $-^{\mathrm{e}}$ & $119.9(5)$ \\
\hline $\mathrm{C}_{2}-\mathrm{C}_{1}-\mathrm{C}_{7}$ & 122.7 & (18) & $121.0(2)$ & 124.2 & (25) & $118.6(5)$ \\
\hline
\end{tabular}




\begin{tabular}{|c|c|c|c|c|c|c|}
\hline $\mathrm{C}_{1}-\mathrm{C}_{7}=\mathrm{O}_{8}$ & 119.4 & (16) & $126.1(2)$ & 121.1 & (24) & $125.3(5)$ \\
\hline $\mathrm{C}-\mathrm{C}_{\text {ring }}-\mathrm{O}_{\mathrm{Me}}{ }^{\mathrm{f}}$ & 112.2 & & $114.2(2)$ & 114.5 & & $114.3(5)$ \\
\hline $\mathrm{C}-\mathrm{C}_{\text {ring }}-\mathrm{O}_{\mathrm{H}} \mathrm{g}$ & 119.1 & $(12)$ & $121.8(2)$ & 121.5 & $(12)$ & $122.4(5)$ \\
\hline $\mathrm{C}_{\text {ring }}-\mathrm{O}-\mathrm{C}_{\mathrm{Me}}$ & 121.7 & (29) & $117.3(2)$ & 123.8 & (26) & $117.4(5)$ \\
\hline
\end{tabular}

${ }^{\text {a }}$ See Fig. 1 for the atom numbering and the definitions of the conformers.

${ }^{\mathrm{b}}$ Present study. Values in parentheses are estimated error limits $(3 \sigma)$ referring to the last significant digit.

${ }^{\mathrm{c}}$ Ref. [5]. The average of the four nonequivalent molecules contained in the symmetry unit. Values in parentheses are estimated error limits referring to the last significant digit.

${ }^{\mathrm{d}}$ Ref. [6]. Values in parentheses are estimated error limits $(3 \sigma)$ referring to the last significant digit.

${ }^{\mathrm{e}}$ Dependent parameter.

${ }^{\mathrm{f}} \mathrm{C}_{4}-\mathrm{C}_{3}-\mathrm{O}_{9}$ angle for vanillin and $\mathrm{C}_{3}-\mathrm{C}_{4}-\mathrm{O}_{10}$ angle for isovanillin.

${ }^{\mathrm{g}} \mathrm{C}_{3}-\mathrm{C}_{4}-\mathrm{O}_{11}$ angle for vanillin and $\mathrm{C}_{4}-\mathrm{C}_{3}-\mathrm{O}_{9}$ angle for isovanillin. 
Table 10

Comparison of the gas-phase structures of vanillin, isovanillin and related molecules determined by electron diffraction ${ }^{\text {a }}$

\begin{tabular}{|c|c|c|c|c|c|c|c|}
\hline Parameters ${ }^{b}$ & \multicolumn{2}{|c|}{ Vanillin $^{c}$} & \multicolumn{2}{|c|}{ Isovanillin $^{c}$} & Benzaldehyde $^{\mathrm{d}}$ & Anisole $^{\mathrm{e}}$ & Phenol ${ }^{\mathrm{f}}$ \\
\hline \multicolumn{8}{|c|}{ Bond lengths $(\AA)$} \\
\hline$<\mathrm{C}-\mathrm{C}>_{\text {ring }}$ & 1.397 & & 1.402 & & $1.397(3)$ & $1.399(3)$ & $1.399(3)$ \\
\hline $\mathrm{C}_{\text {ring }}-\mathrm{C}_{\text {aldehyde }}$ & 1.471 & $(4)$ & & (4) & & & \\
\hline $\mathrm{C}=\mathrm{O}$ & 1.214 & $(8)$ & 1.221 & (9) & $1.212(3)$ & & \\
\hline $\mathrm{C}_{\text {ring }}-\mathrm{O}_{\mathrm{Me}}$ & 1.374 & ) & 1.369 & 1 & & $1.363(15)$ & \\
\hline $\mathrm{C}_{\text {ring }}-\mathrm{O}_{\mathrm{H}}$ & 1.361 & $\zeta(9)$ & 1.357 & \}$(9)$ & & & $1.381(4)$ \\
\hline $\mathrm{O}-\mathrm{C}_{\mathrm{Me}}$ & 1.428 & J & 1.422 & J & & $1.425(15)$ & \\
\hline \multicolumn{8}{|c|}{ Bond angles $\left({ }^{\circ}\right)$} \\
\hline $\mathrm{C}_{2}-\mathrm{C}_{1}-\mathrm{C}_{\text {aldehyde }}$ & 122.7 & $(18)$ & 124.6 & $(25)$ & $120.9(6)$ & & \\
\hline $\mathrm{C}_{1}-\mathrm{C}_{\text {aldehyde }}=\mathrm{O}$ & 119.4 & (16) & 121.3 & (24) & $123.6(4)$ & & \\
\hline $\mathrm{C}_{1}-\mathrm{C}_{\text {aldehyde }}-\mathrm{H}$ & 115.1 & $-^{\mathrm{g}}$ & 115.1 & $-^{\mathrm{g}}$ & $115.1(16)$ & & \\
\hline $\mathrm{C}-\mathrm{C}_{\text {ring }}-\mathrm{O}_{\mathrm{Me}}{ }^{\mathrm{h}}$ & 112.2 & & 114.4 & & & $116.0-\mathrm{g}$ & \\
\hline $\mathrm{C}-\mathrm{C}_{\text {ring }}-\mathrm{O}_{\mathrm{H}}{ }^{\mathrm{i}}$ & 119.1 & $(12)$ & 121.2 & $(12)$ & & & $121.2(12)$ \\
\hline $\mathrm{C}_{\text {ring }}-\mathrm{O}-\mathrm{C}_{\mathrm{Me}}$ & 121.7 & (29) & 123.8 & (26) & & $120.0(20)$ & \\
\hline $\mathrm{C}_{\text {ring }}-\mathrm{O}-\mathrm{H}$ & 106.4 & 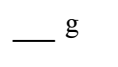 & 106.4 & $-_{\mathrm{g}}$ & & & $106.4(37)$ \\
\hline
\end{tabular}

${ }^{a}$ Values in parentheses are estimated error limits referring to the last significant 
digit.

${ }^{\mathrm{b}}$ See Fig. 1 for the atom numbering.

${ }^{\mathrm{c}} r_{\mathrm{g}}$ and $\angle_{\alpha}$ of the s-cis conformer (present study). Error limits are $3 \sigma$.

${ }^{\mathrm{d}} r_{\mathrm{g}}$ and $\angle{ }_{\alpha}($ Ref. [17]).

${ }^{\mathrm{e}} r_{\mathrm{g}}$ distances were calculated from the $r_{\mathrm{a}}$ distances and mean amplitudes reported in Ref. [23]. No shrinkage correction was applied for the bond angles.

${ }^{\mathrm{f}} r_{\mathrm{g}}$ and $\angle_{\alpha}$ (Ref. [18]).

${ }^{\mathrm{g}}$ Assumed.

${ }^{\mathrm{h}} \mathrm{C}_{4}-\mathrm{C}_{3}-\mathrm{O}_{9}$ angle for vanillin, $\mathrm{C}_{3}-\mathrm{C}_{4}-\mathrm{O}_{10}$ angle for isovanillin and the corresponding angle for anisole.

${ }^{\mathrm{i}} \mathrm{C}_{3}-\mathrm{C}_{4}-\mathrm{O}_{11}$ angle for vanillin, $\mathrm{C}_{4}-\mathrm{C}_{3}-\mathrm{O}_{9}$ angle for isovanillin and the corresponding angle for phenol. 


\section{Figure captions}

Fig. 1. Molecular models and atom numberings for the possible conformers of vanillin, isovanillin and ethylvanillin.

Fig. 2. Experimental (open circles) and theoretical (solid curves) molecular scattering intensities of vanillin, isovanillin and ethylvanillin; $\Delta s M(s)=s M(s)^{\text {obs }}-s M(s)^{\text {calc }}$. The theoretical curves were calculated from the best-fit parameters.

Fig. 3. Experimental radial distribution curves of vanillin, isovanillin and ethylvanillin; $\Delta f(r)=f(r)^{\text {obs }}-f(r)^{\text {calc }}$. Distance distributions are indicated by vertical bars. 


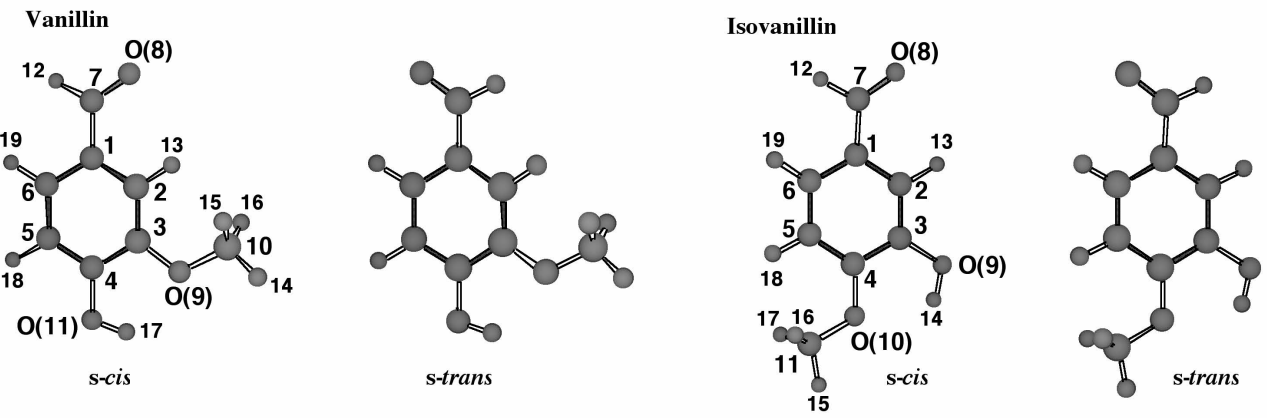

\section{Ethylvanillin}
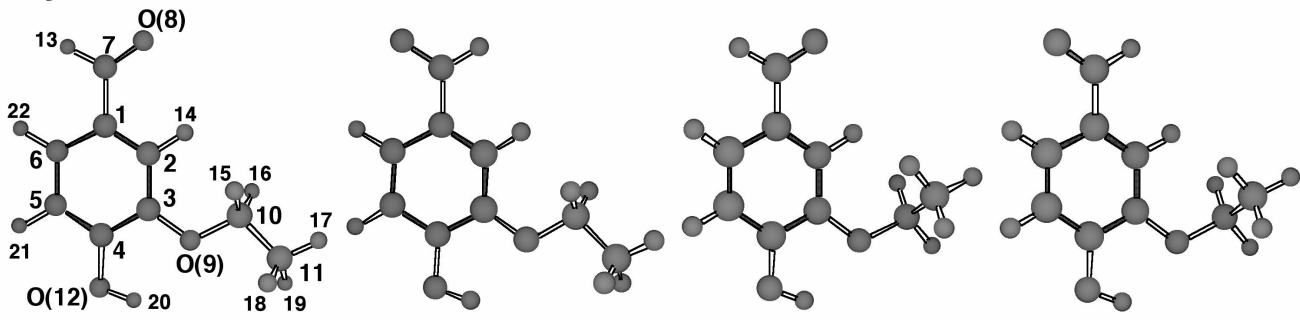


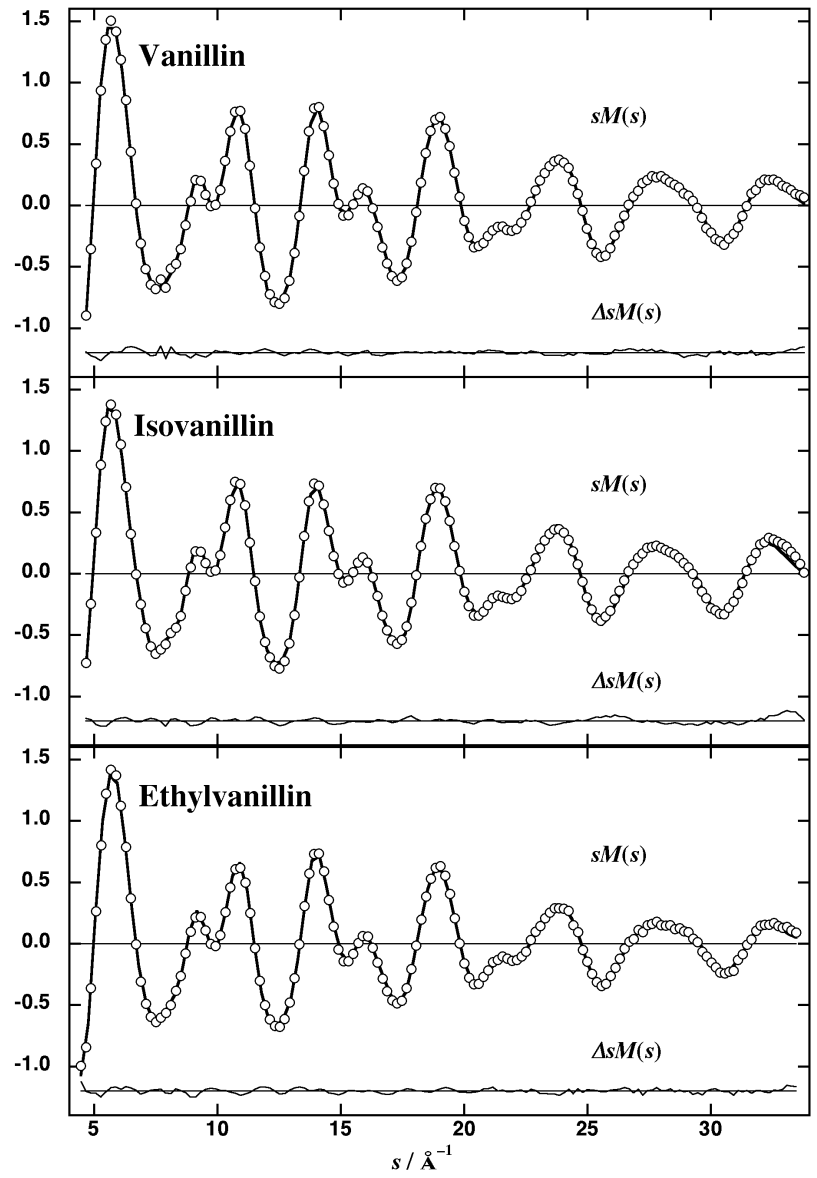




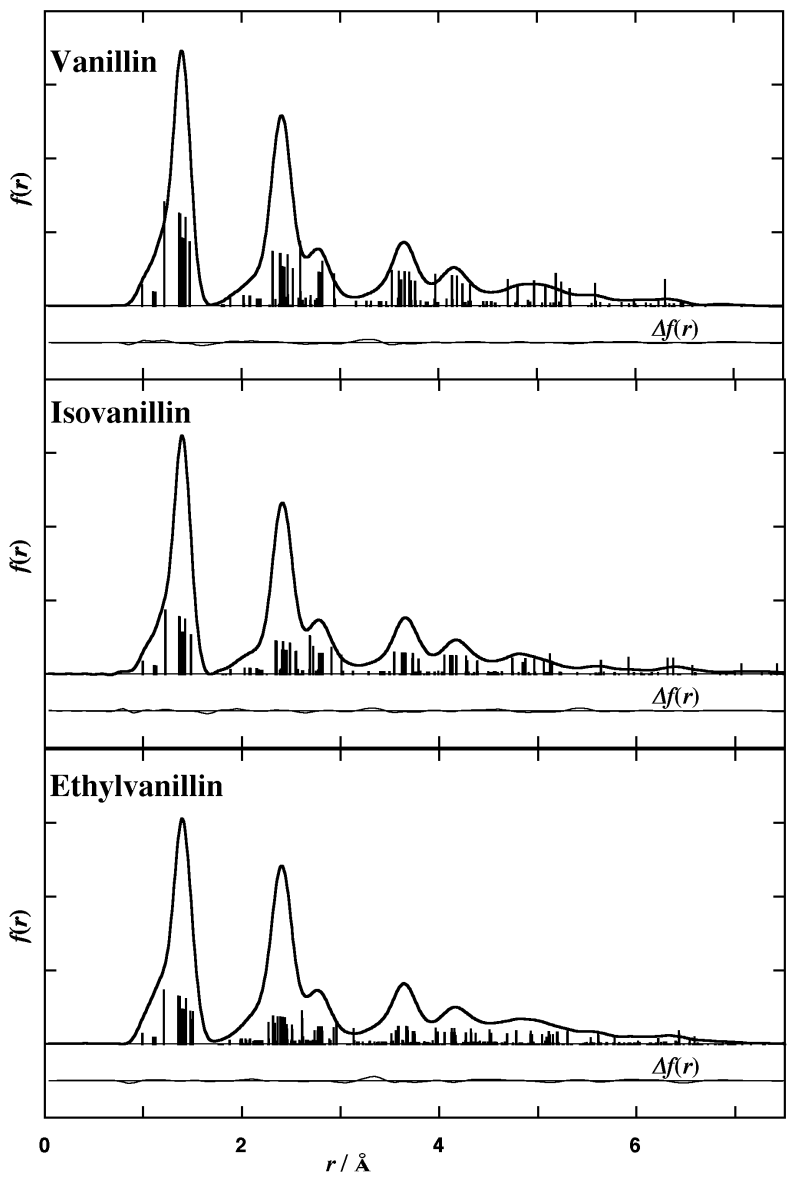

